\title{
Glacial hydrologic conditions in the Black Sea reconstructed using geochemical pore water profiles
}

\author{
G. Soulet ${ }^{a,}{ }^{*}, G$. Delaygue ${ }^{a, 1}$, C. Vallet-Coulomb ${ }^{a}$, M.E. Böttcher ${ }^{b, 2}$, C. Sonzogni ${ }^{a}$, G. Lericolais $^{c}$ and E. \\ Bard $^{\mathrm{a}}$
}

\begin{abstract}
a CEREGE, UMR6635, CNRS Université Paul Cézanne Aix-Marseille III, Collège de France, Europôle de l'Arbois, BP 80, 13545 Aix-en-Provence Cedex 04, France

${ }^{\mathrm{b}}$ Max Planck Institute of Marine Microbiology, D-28359, Bremen, Germany

${ }^{\mathrm{C}}$ IFREMER, Centre de Brest, Géosciences Marines BP70, F-29280 PLOUZANE cedex, France

${ }^{1}$ Present address: LGGE, 38402 Saint-Martin-d'Hères Cedex (France).

${ }^{2}$ Present address: Leibniz Institute for Baltic Sea Research, Geochemistry and isotope Geochemistry Unit, Marine Geology Section, Seestr.15 D-18119 Warnemünde, Germany.
\end{abstract}

*: Corresponding author : G. Soulet, Tel.: +33 04425074 25, email address : soulet@cerege.fr

\begin{abstract}
:
Chloride and $\delta^{18} \mathrm{O}$ compositions of interstitial water extracted from a long sediment core retrieved from the NW coast of the Black Sea allowed us to constrain the main hydrologic changes of the Back Sea during the Late Pleistocene and Holocene. Prior to its reconnection with the Mediterranean Sea (through the Marmara Sea) at approximately 9000 calendar yr before present (9 ka cal BP), the Black Sea has evolved as a fresh to brackish water lake. At the time of reconnection, hydrologic changes were drastic. Bottom water salinities changed from a few psu (practical salinity unit) to $\approx 22 \mathrm{psu}$. Since solutes in the interstitial water column within sediments are advected and diffused the measured concentrations do not reflect those of past bottom waters. In order to reconstruct these former concentrations, we used an advection/diffusion model. Different scenarios of bottom water chloride and $\delta^{18} \mathrm{O}$ variations were accounted for in this model in order to simulate "present day" vertical profiles for concentrations of interstitial water in order to compare them to measured ones. The comparison suggests that the glacial Black Sea was a homogeneous freshwater lake (with a $\delta^{18} O$ of $\approx-10 \%$ and a salinity of $\approx 1 \mathrm{psu}$ ). Modern hydrologic conditions would only have been reached at $\approx 2 \mathrm{ka} \mathrm{cal} \mathrm{BP}$, concomitant with the onset of coccolith-rich thin layers that characterize modern basin sediments. Such delayed salinization (over $\sim 7000 \mathrm{yr}$ ) in the basin may have been due to higher precipitation during the early Holocene. We also simulated the impact of a catastrophic reconnection and a smoother reconnection. Both salinity scenarios lead to undistinguishable modelled "present day" profiles, indicating that the precise impact of the last reconnection was lost due to the advection/diffusion processes.
\end{abstract}

Keywords: Black Sea; interstitial water; salinity; water isotopes; advection/diffusion modelling; deglaciation 


\section{Introduction}

Today, the Black Sea is a marine water body but it has been oscillating between lacustrine and marine stages following, respectively, glacial and interglacial global sea level changes. The penultimate Black Sea marine stage occurred during the previous interglacial (Schrader, 1979; Stoffers et al., 1978). The Black Sea became a lake more or less at the onset of the last glacial when global sea level dropped below its outlet (Arz et al., 2008; Zubakov, 1988). Reconnection between the Mediterranean Sea and the Black Sea, through the Marmara Sea, occurred at the end of the last deglaciation during global sea level rise. Previous studies agree with the timing of the last connection between the Black Sea and the Mediterranean Sea, recently dated to $8.4{ }^{14} \mathrm{C}$ ka BP (Major et al., 2006; Marret et al., 2009). However, the mechanism of refilling in the Black Sea is still a matter of debate since researchers have proposed the Black Sea abrupt "Flood Hypothesis" (Ryan et al., 1997, 2003) or the continuous "Outflow Hypothesis" (Aksu et al., 2002a; Hiscott et al., 2007).

In oceans or lakes, bottom water is continuously trapped within the pores of sediment and buried together with the sediment. Since bottom water geochemistry is directly linked to basin hydrology and regional climate changes, interstitial water composition is useful for reconstructing hydrologic and climatic changes. Sixty years ago, Bruyevich (1952) published measurements of interstitial fluid composition providing the first direct evidence of marked fluctuations in Black Sea salinity during the Quaternary. However, the measured chloride concentration of the pore water does not correspond to the past bottom water chloride content due to molecular diffusion and advection within sediments (e.g. Jørgensen et al., 2001, 2004; Manheim and Chan, 1974; Manheim and Schug, 1978). Not only do these processes influence the age relationship between the sediment and the pore water, but also alter the original water composition. Manheim and Chan (1974) attempted to correct the chloride concentration for these modifications and provided the first quantitative paleo-salinity estimation of 6 psu (practical salinity unit) for Black Sea bottom water, immediately before its reconnection to the Marmara Sea. The correction was based on the steady state solution of the diffusion equation, and, unfortunately, ruled out transient changes from the procedure. Recently, this type of approach was applied more precisely using numeric models and highresolution geochemical profiles in order to reconstruct the salinity, the $\delta^{18} \mathrm{O}$, and the $\delta \mathrm{D}$ of oceanic deep water in several places (e.g. Adkins and Schrag, 2003; Paul et al., 2001; Schrag and DePaolo, 1993; Schrag et al., 1996) during the Last Glacial Maximum (LGM). Following these latter works, we applied this method to high resolution geochemical profiles from Black Sea sediments.

Besides the strong controversy surrounding the conditions of the last reconnection in the Black Sea, the salinity just prior to the last reconnection is also a matter of debate. On one hand, a fresh Black Sea "Lake" (e.g. Ballard et al., 2000; Major et al., 2002; Ryan et al., 1997) would have allowed coastal farming on exposed shelves. As a consequence, a catastrophic flood would have accelerated dispersion of Neolithic farmers into the interior of Europe, providing a historical basis for widespread Deluge myths (Ryan and Pitman, 1998). On the other hand, a brackish or salty Black Sea (e.g. Mudie et al., 2002a; Yanko-Hombach, 2007) would have prevented any massive settlement along the Black Sea coast. Therefore, determining the salinity of the isolated Black Sea is of interest in the context of ongoing discussions regarding the impacts of the last reconnection. An accurate salinity estimation is also needed in order to better understand paleo-environmental proxies of the isolated Black Sea since currently there is no analogue to this ancient giant lake.

In order to provide new insights into these topics, we estimated the composition of Black Sea water (salinity, $\delta^{18} \mathrm{O}_{\text {water }}$ ) during its last fresh to brackish phase. We also tried to constrain salinity and $\delta^{18} \mathrm{O}_{\text {water }}$ changes in the NW Black Sea shelf since the LGM, as well as characterize the rate of basin salinization. 


\section{Methods}

\subsection{Hydrography and Site location}

The semi-enclosed Black Sea basin is connected to the Mediterranean Sea via the Marmara Sea and two shallow straits. The Bosphorus Strait ( $\sim 35 \mathrm{~m}$ deep) links the Black Sea to the Marmara Sea. The Dardanelles Strait ( $>00 \mathrm{~m}$ deep) links the Marmara Sea to the Mediterranean Sea. Currently, the hydrology of the system is characterized by an estuarinetype circulation (Figure 1). Therefore, the Black Sea is characterized by a stable pycnocline between 100 to 200 meters in water depth that separates brackish surface water ( 18 psu) from more saline deep water ( 22 psu) of Mediterranean origin (Özsoy et al., 2002). Stratification strongly reduces the ventilation of deep water leading to anoxic conditions below $\sim 150 \mathrm{~m}$ water depth. The isotopic composition of Black Sea water reflects this water stratification: values of $\delta^{18} \mathrm{O}$ vary from approximately $-2.8 \%$ in the less saline upper $50 \mathrm{~m}$ to approximately $-1.8 \%$ in more saline water below $200 \mathrm{~m}$ (Rank et al., 1999).

MD04-2770 and MD04-2790 sister cores (see Appendix A for a brief core description) were recovered exactly at the same location in the NW Black Sea shelf $\left(44^{\circ} 13^{\prime} \mathrm{N}, 29^{\circ} 59^{\prime} \mathrm{E}\right)$ in the Danube deep sea fan (Figure 2), during the 2004 Assemblage-1 cruise within the European ASSEMBLAGE project (EVK3-CT-2002-00090). The coring site was chosen on the basis of a seismic profile determined during the Ifremer BlaSON2 survey in 2002 and shot on the slope away from the Danube Canyon system. The seismic profile (Figure 3) shows a thick sediment sequence that presents a regular succession of layers neither deformed nor structured by tectonic movements. Additionally, the seismic profile does not provide any evidence of a turbiditic sequence or a fluid seepage in the investigated area. Therefore, the coring site is expected to preserve undisturbed pore water and to only record climatic and/or hydrologic changes. Currently, the coring site lies within Black Sea bottom water at a water depth of $350 \mathrm{~m}$, and is characterized by a salinity of $\sim 22$ psu (Özsoy et al., 2002) and by $\delta^{18} \mathrm{O}$ values of approximately $-1.8 \%$ (Rank et al., 1999).

\subsection{Interstitial water geochemistry}

MD04-2770 sediment samples were taken onboard for pore water extraction at section ends immediately after cutting core sections. A sub-sampling was performed along the sections in order to improve data resolution. Samples were squeezed at $4^{\circ} \mathrm{C}$ with a pore water sediment squeezer. Interstitial water samples were stored in vials wrapped with Parafilm ${ }^{\circledR}$ and were kept refrigerated. Chloride concentrations were determined as described by Jørgensen et al. (2001) after a 100-fold dilution of pore water by non-suppressed ion chromatography (Waters, column IC-Pack ${ }^{\mathrm{TM}}, 50 \times 4.6 \mathrm{~mm}$ ). The injection volume was $100 \mu \mathrm{l}$, the flow rate was $1.0 \mathrm{~mL}$. $\mathrm{min}^{-1}$, and the eluent was $1 \mathrm{mM}$ isophtalate buffer in $10 \%$ methanol adjusted to $\mathrm{pH} 4.7$ with a saturated $\mathrm{Na}$-borohydrate solution. The typical relative uncertainty was $\pm 5 \% . \delta^{18} \mathrm{O}$ values of the water were determined by mass spectrometry at Cerege (Aix en Provence, France). Water samples were equilibrated with $\mathrm{CO}_{2}$ gas in an automated HDO ThermoFinnigan equilibrating unit and measured on a dual inlet Delta Plus mass spectrometer. Results are reported as delta values, representing deviations in per mil (\%) from VSMOW. We performed replicate analyses on all of the measured samples. The total uncertainty for the $\delta^{18} \mathrm{O}$ value was less than $0.05 \%$ o $(1 \sigma)$. 


\subsection{Interstitial water modelling}

\subsubsection{Diffusion/Advection model}

Interstitial fluid profiles were modelled using the one-dimensional tracer diffusion/advection equation (Berner, 1980): $\phi(z) \cdot \frac{\partial C(z, t)}{\partial t}=\frac{\partial}{\partial z}\left(\phi(z) \cdot \frac{D(z, t)}{\theta(z)^{2}} \cdot \frac{\partial C(z, t)}{\partial z}\right)-\phi(z) \cdot u(z, t) \cdot \frac{\partial C(z, t)}{\partial z}$

where $z$ is the depth below the water-sediment interface (i.e. below sea floor) and $t$ is the time. $C$ is the concentration of the interstitial water tracer of interest, $\Phi$ is the porosity, $\theta$ is the tortuosity, and $\mathrm{D}$ is the molecular diffusivity of the geochemical tracer. Empirical functions of D were taken from Boudreau (1997) and references therein. Porosity was calculated as a function of depth ( $\mathrm{z}$ ) based on a smooth fit of the measured data (Appendix B). The use of tortuosity $(\theta)$ followed the model of Boudreau and Meysman (2006). The advection of interstitial water was accounted for using the vertical velocity (u), which corresponds to the water flux due to compaction which occurs during sediment burial. In addition, a possible upward or downward water flux (v) due to geologic settings was introduced. Assuming the steady state compaction, the fluid velocity is (Luff and Wallmann, 2003):

$u(z, t)=\frac{\phi_{\infty} \cdot \frac{1-\phi_{0}}{1-\phi_{\infty}} \cdot S R(t)-v_{0} \phi_{0}}{\phi(z)}$

where SR is the sedimentation rate, $v_{0}$ is the value of $v$ at the top of the sediment column, and $\Phi_{0}$ is the porosity at the water-sediment interface. Steady state compaction is based on the assumption that there is a depth below which porosity does not change $\left(\Phi_{\infty}\right)$ (Appendix B). Sedimentation rate evolution was derived from the sister core MD04-2790 age model (Appendix A).

We developed a finite difference diffusion-advection code in order to integrate the diffusion/advection differential Equation (1) in time. The sediment column height was set to $100 \mathrm{~m}$. The duration of the diffusion/advection simulation was set to $20 \mathrm{Kyr}$. The initial vertical geochemical profile was assumed to be homogeneous at the $\mathrm{C}_{\mathrm{LGM}}$ value all along the length domain. $\mathrm{C}_{\mathrm{LGM}}$ is the tracer concentration $\left([\mathrm{Cl}]_{\mathrm{LGM}} ; \delta^{18} \mathrm{O}_{\mathrm{LGM}}\right.$ ) of the Black Sea bottom water at the LGM (i.e. approximately $20 \mathrm{Kyr}$ ago). The model top boundary condition was forced with the time evolution of the water-sediment interface concentration using the tracer of interest $\left([\mathrm{Cl}] \mathrm{t}(\mathrm{t})\right.$ or $\left.\delta^{18} \mathrm{O}(\mathrm{t})\right)$. At each time step, the model accounted for the new boundary condition at the top, and vertically advected and diffused the tracers $\left(\left[\mathrm{Cl}^{-}\right]\right.$and ${ }^{18} \mathrm{O}$ ), according to Equation (1). At the end of the $20 \mathrm{Kyr}$ simulation, the modelled "present day" vertical profile could then be compared with the one measured from interstitial water by calculating a Root Mean Square (RMS) distance.

\subsubsection{Model forcing}

We tested different probable scenarios of $\left[\mathrm{Cl}^{-}\right]$and $\delta^{18} \mathrm{O}$ changes in the bottom water (including LGM concentration tracers $\left[\mathrm{Cl}_{\mathrm{LGM}}\right.$ and $\delta^{18} \mathrm{O}_{\mathrm{LGM}}$ ), as well as different advection values $\left(\mathrm{V}_{0}\right)$.

Using different data enabled us to roughly constrain past variations of $\left[\mathrm{Cl}^{-}\right]$and $\delta^{18} \mathrm{O}$ in bottom water. As described below, we combine these data to determine different probable scenarios as inputs to our advection-diffusion model. In all simulations, Black Sea glacial values [Cl] $]_{\text {LGM }}$ and $\delta^{18} \mathrm{O}_{\text {LGM }}$ were tested. We also tested two different sets of scenarios for $\left[\mathrm{Cl}^{-}\right.$ ] variations in order to characterize the refilling conditions of the Black Sea "Lake" at the reconnection with the Marmara Sea: the "Outflow" vs. the "Flood" hypotheses (Figure 4A\&B). 
In scenarios of $\left[\mathrm{Cl}^{-}\right]$variations, the age at which Black Sea bottom water reached modern salinity was also tested (Figure 4A\&B), whereas the age of the last reconnection was considered as a known parameter and set to $9 \pm 0.5 \mathrm{ka}$ calBP. The age and its uncertainty corresponded to the radiocarbon age of the last reconnection $\left(8.4{ }^{14} \mathrm{C}\right.$ ka BP; Major et al., 2006; Marret et al., 2009), calibrated (Reimer et al., 2009) after correction by a reservoir age ranging from 0 to $900 \mathrm{yr}$ depending upon water depth (Kwiecien et al., 2008).

In the following (text and figures), the chloride content was converted into salinity by applying a factor of $1.807\left(\mathrm{~S}=1.807 \times\left[\mathrm{Cl}^{-}\right]\right.$; Cox et al., 1967) for easier comprehension. Scenarios of salinity changes in the bottom water were built differently for both reconnection conditions. Those reflecting the "Outflow" hypothesis (Aksu et al., 2002a; Hiscott et al., 2007) were built by linearly increasing the salinity from its unknown glacial value $\left(\mathrm{S}_{\mathrm{LGM}}\right)$ to a modern value of 22 psu between the reconnection time and the time at which the salinity was expected to have remained stable at 22 psu. Salinity scenarios reflecting the "Flood" hypothesis (Ryan et al., 1997, 2003) were built as the previous ones, with a sudden salinity increase at the time of the reconnection. The amplitude of this increase (Table 1) due to the "flood" was calculated by estimating the volume (Myers et al., 2003) of saline water (38 psu) required to fill the isolated Black Sea lowered to -90 meters below sea level (mbsl) (Popescu et al., 2004).

Carbonate $\delta^{18} \mathrm{O}$ data from fresh to brackish ostracod shells (a type of benthic fauna) from cores recovered in the vicinity of our study area (Bahr et al., 2006, 2008) constrained the amplitude and the direction of bottom water $\delta^{18} \mathrm{O}$ changes during the isolated phase before the reconnection. Therefore, we built the $\delta^{18} \mathrm{O}$ evolutions of the bottom water (Figure 4C) by roughly mimicking the carbonate data. Bottom water $\delta^{18} \mathrm{O}$ remained constant at the unknown glacial value $\left(\delta^{18} \mathrm{O}_{\text {LGM }}\right)$ until $14.8 \mathrm{ka}$ calBP then linearly increased up to $-2.8 \%$ vs. VSMOW at $8 \mathrm{ka}$ calBP. The latter value corresponds to an ostracod $\delta^{18} \mathrm{O}$ value of $0.68 \%$ vs. PDB (Bahr et al., 2006), obtained using a transfer function provided by Rösler and Lange (1976) applying the present day bottom water temperature of $9^{\circ} \mathrm{C}$. The value is very close to the present day bottom water $\delta^{18} \mathrm{O}(-2.2 \%)$. The steady increase in the bottom water $\delta^{18} \mathrm{O}$ is partly linked to global climate warming during deglaciation, which has increased the $\delta^{18} \mathrm{O}$ of precipitation feeding (directly or indirectly) the Black Sea lake (Bahr et al., 2006)

Starting at the reconnection to the global ocean, an increase in Black Sea salinity led to the disappearance of fresh to brackish ostracods. Therefore, ostracod $\delta^{18} \mathrm{O}$ data do not exist for the past $8 \mathrm{kyr}$. Since bottom water $\delta^{18} \mathrm{O}$ at $8 \mathrm{ka}$ cal BP was very close to the present day value and without any other constraint, we constructed the last part of the bottom water $\delta^{18} \mathrm{O}$ scenarios by assuming that $\delta^{18} \mathrm{O}_{\text {water }}$ increased linearly from $-2.8 \%$ o to the present value of $2.2 \%$.

\subsubsection{Model solution}

Bottom water scenarios were independently tested for $\left[\mathrm{Cl}^{-}\right]$and $\delta^{18} \mathrm{O}$ for different initial (glacial) values $\left[\mathrm{Cl}^{-}\right]_{\mathrm{LGM}} / \delta^{18} \mathrm{O}_{\mathrm{LGM}}$ and different vertical fluid advection $\mathrm{v}_{0}$. For each scenario, the model simulated a "present day" vertical profile of $\left[\mathrm{Cl}^{-}\right]$and $\delta^{18} \mathrm{O}$ in the sediment which can be compared to measurements by calculating an RMS distance. We retained the ones leading to the smallest RMS distance between modelled and measured tracer profiles as probable scenarios.

Furthermore, vertical fluid advection $v_{0}$ is common to both tracers since it originates from the specific geologic settings of the coring site: this additional constraint allowed us to reduce the number of possible scenarios. Cross validation improved the robustness of our results.

\section{Results}

\subsection{Measured geochemical profiles}


The dissolved chloride concentration increased upward from approximately $1.1 \mathrm{~g} \cdot \mathrm{L}^{-1}$ (equivalent to a salinity of $2 \mathrm{psu}$ ) at the core base to $12.1 \mathrm{~g} \cdot \mathrm{L}^{-1}$ (equivalent to a salinity of 21.9 $\mathrm{psu}$ ) at the core top (Figure $5 \mathrm{~A}$ ). The latter value is consistent with current salinity in the Black Sea at a depth of approximately $300-400$ m (i.e. below the pycnocline (Figure 1)). The $\delta^{18} \mathrm{O}$ of interstitial water increased upward from much depleted values (-8.3\%o vs. VSMOW) to more enriched ones (-2.1\% vs. VSMOW) (Figure 5B). The latter value is in good agreement with current bottom water data for this water depth (Rank et al., 1999; Figure 1).

The obtained chloride profile as well as $\delta^{18} \mathrm{O}$ profile (available in Table 2) point to the presence of "fresh" to low saline, $\mathrm{H}_{2}{ }^{18} \mathrm{O}$-depleted pore water buried in Late Pleistocene sediments and are related to recent marked fluctuations in water salinity and $\mathrm{H}_{2}{ }^{18} \mathrm{O}$ contents.

\subsection{Modelled geochemical profiles}

Among the numerous $S$ and $\delta^{18} O$ scenarios tested (Figure 4), some of them lead to "present day" modelled profiles that fit measured profiles for a common value $v_{0}$ (conditions used to validate the tested scenario). The range of the additional advection flow $\left(\mathrm{v}_{0}\right)$ was found to be $35 \pm 10 \mathrm{~cm} / \mathrm{Kyr}$.

The best fit to the $\left[\mathrm{Cl}^{-}\right]$data was obtained for a $S_{L G M}$ value of $1 \pm 0.35 \mathrm{psu}$, only if the Black Sea reached a modern salinity value at $2 \pm 0.5 \mathrm{ka}$ calBP (Figure 6A\&B; Figure 4A\&B). The finding is valid for both the "Outflow" and the "Flood" hypotheses.

The best fit to the $\delta^{18} \mathrm{O}$ data was obtained for a $\delta^{18} \mathrm{O}_{\mathrm{LGM}}$ of $-10.1 \pm 0.2 \%$ o (Figure 6C; Figure $4 C$ ). An independent test of this estimate was provided by the carbonate $\delta^{18} \mathrm{O}$ data from ostracod shells (benthic fauna) in cores recovered in the vicinity of our study area (Bahr et al., 2006). A transfer function (Rösler and Lange, 1976) is related to the carbonate $\delta^{18} \mathrm{O}$ value, the water $\delta^{18} \mathrm{O}$ value, and the water temperature. By applying the transfer function to ostracod $\delta^{18} \mathrm{O}$ data spanning the interval from 20 to $16.5 \mathrm{ka}$ calBP, and by using the inferred glacial bottom water $\delta^{18} \mathrm{O}_{\text {LGM }}$ value of $-10.1 \pm 0.2 \%$, a bottom water temperature of $\sim 4^{\circ} \mathrm{C}$ was determined. This is very close to the temperature of the density maximum for fresh water, which is expected for bottom waters during a glacial period. Such consistency between the carbonate data and our reconstruction for glacial waters independently supports our results.

\section{Discussion}

\subsection{Robustness of the modelling results}

Our modelling procedure is based on several parameters: the porosity, the diffusion coefficient, the advection $\left(v_{0}\right)$, and the sedimentation rate, as well as the initial geochemical profile. These parameters are discussed below.

\subsubsection{Does interstitial water geochemistry only reflect Black Sea hydrologic}

\section{changes?}

Evaluating the closeness (RMS distance) between measured and "present day" modelled profiles for [ $\left.\mathrm{Cl}^{-}\right]$and $\delta^{18} \mathrm{O}$ is relevant only if the measured profiles have not been affected by other diagenetic processes other than advection/diffusion. The main additional process that may modify chloride and $\mathrm{H}_{2}^{18} \mathrm{O}$ concentrations under these settings is the dissociation of gas hydrates, either in situ or during core retrieval. Hydrate dissociation would release water and, consequently, would decrease the salinity of the interstitial water. However, the theoretical 
minimum water depth for hydrate formation is $725 \mathrm{mbsl}, \sim 400 \mathrm{~m}$ below the core site water depth (Naudts et al., 2006 and references therein). Since our coring site is well outside of the hydrate stability field, and has always been, gas hydrate dissociation and the corresponding interstitial water freshening can be excluded. Furthermore, water released during hydrate dissociation enriches the interstitial water in $\mathrm{H}_{2}{ }^{18} \mathrm{O}$ (Jenden and Gieskes, 1983) which, if it had actually occurred, would not be consistent with the observed continuous down-core decrease in $\delta^{18} \mathrm{O}$ (Figure $5 \mathrm{~B}$ ). At the coring site, the chloride content and the $\delta^{18} \mathrm{O}$ can be considered as conservative tracers that are only influenced by advection and diffusion. Therefore, we are confident that chloride content and $\delta^{18} \mathrm{O}$ interstitial water profiles only reflect changes in bottom water chemistry, when starting from fresh-brackish conditions that prevailed during the last glacial period, indicating that our measured geochemical profiles can be used to validate our modelling results.

\subsubsection{Sensitivity to model parameters}

The majority of model parameters (Figure 4) were either measured $(\Phi, \mathrm{SR})$ or taken from the literature $(D, \theta)$. Parameter uncertainties are difficult to assess and propagate in the model. Instead we evaluated the sensitivity of the modelled geochemical profiles to each parameter. $\left[\mathrm{Cl}^{-}\right]$and $\delta^{18} \mathrm{O}$ profiles, simulated by varying the sedimentation rate by $\pm 25 \%$ fell within the measurement uncertainties. Therefore, our results are not very sensitive to this parameter. By varying the effective diffusivity $\left(\frac{\phi \cdot D}{\theta^{2}}\right)$ by $\sim 5 \%$, the simulated profiles differed in salinity by less than $0.3 \mathrm{psu}$, and in $\delta^{18} \mathrm{O}$ by less than $0.1 \%$. We also tested the impact of the unknown advection parameter $v_{0} . v_{0}$ simulates a possible fluid flow induced from below by specific geologic settings. By varying $v_{0}$ within $10 \mathrm{~cm} / \mathrm{Kyr}$, the simulated profiles differed in salinity by less than 0.3 psu and, in $\delta^{18} \mathrm{O}$ by less than $0.1 \%$.

It appears that a $5 \%$ uncertainty in the effective diffusivity and a $\pm 10 \mathrm{~cm} / \mathrm{Kyr}$ uncertainty on $\mathrm{v}_{0}$ had a similar and limited influence on simulated "present day" geochemical profiles. $\mathrm{v}_{0}$ is $\mathrm{a}$ free parameter since it is completely unknown. Therefore, in addition to a potential fluid flow induced by specific geologic settings, $v_{0}$ may account for uncertainties in other parameters. Since the "best fit" value of $v_{0}$ is small $(0.035 \mathrm{~mm} / \mathrm{yr})$, it is difficult to estimate which part of $v$ actually corresponds to a fluid flow and which part may correspond to the uncertainty of other parameters. One way to address this question would be to derive the value of the effective diffusivity (more precisely its relationship with porosity) required to fit our measurements without any advection (v). However, this was beyond the scope of the current study.

\subsubsection{Initial and boundary conditions of the model}

In order to integrate Equation 1 over time, we needed to prescribe the vertical profiles of tracer concentrations at the beginning of the simulation (i.e., $20 \mathrm{Kyr}$ ago) and fix the tracer concentration at the bottom of the sedimentary column. Both the initial profile and the lower boundary condition had a significant influence on the results since: 1) diffusion is governed by the concentration gradient and, 2) upward advection transports solutes from lower depths. We used a $100 \mathrm{~m}$-long homogeneous $\mathrm{C}_{\mathrm{LGM}}$ profile as the initial condition based on the following physical considerations. First, the original geochemistry of the bottom water is well preserved in the sediments. A rough measure of the rate at which diffusional migration competes with the sedimentation rate is the ratio of the effective diffusion coefficient to the sedimentation rate $\left(S H=\frac{\phi \cdot D}{\theta^{2} \cdot S R}\right.$, where $\left.\Phi=0.6\right)$, expressed as a scale height (Manheim and Schug, 1978). Throughout glacial history in the Black Sea, the sedimentation rate at our coring location was very high, typically 100 to $150 \mathrm{~cm} / \mathrm{Kyr}$ (Soulet et al., in prep.), leading to 
scale heights of 16 to $11 \mathrm{~m}$ and 12 to $8 \mathrm{~m}$, respectively for $\delta^{18} \mathrm{O}$ and $\mathrm{Cl}^{-}$. During the late glacial phase of the Black Sea, minor fluctuations in $\delta^{18} \mathrm{O}$ were recorded (Bahr et al., 2006; Kwiecien et al., 2009). Most likely, salinity fluctuations were also minor, since there is no evidence of marine water intrusion in the glacial isolated Black Sea (Table 3) during the last $50 \mathrm{Kyr}$. Hence, $\left[\mathrm{Cl}^{-}\right]$and $\mathrm{H}_{2}{ }^{18} \mathrm{O}$ gradients were likely very small within the interstitial water column. Therefore, the combination of exceptionally rapid sediment deposition at our coring location and minor fluctuations in bottom water salinity and $\delta^{18} \mathrm{O}$ throughout the last glacial must have allowed preservation of the original geochemistry of glacial waters within pores of the sediment column.

Second, the minimum height of the sedimentary column to be represented by the model was few tens of meters, corresponding to the height over which tracers were affected by diffusion and advection during the simulation duration of $20 \mathrm{Kyr}$. Given this duration, and without advection, the Einstein-Smoluchowsky relationship provided an estimation of the length of diffusion of the tracers: $d=\sqrt{\frac{2 \cdot \Delta t \cdot \phi \cdot D}{\theta^{2}}}$ (where $\Delta \mathrm{t}=20 \mathrm{Kyr}$, and $\Phi=0.6$ ). The length is approximately $19 \mathrm{~m}$ and $23 \mathrm{~m}$, respectively, for $\mathrm{Cl}^{-}$and $\delta^{18} \mathrm{O}$. By adding the $\sim 10 \mathrm{~m}$ of sediment deposited at our coring location over the last $20 \mathrm{Kyr}$, indicates that, without advection, only the first third of the $100 \mathrm{~m}$ length domain is significantly modified by diffusion. The effect of upward advection ( $v$ ) is to counteract the downward diffusion of solutes from saline waters. We determined a mean upward advection of $35 \mathrm{~cm} / \mathrm{Kyr}$, indicating that interstitial water geochemistry in our sediment column is impacted by solutes located within the $7 \mathrm{~m}$ of the underlying sediment over a time period of $20 \mathrm{Kyr}$.

Therefore, over the time period of $20 \mathrm{Kyr}$, only the upper first $\sim 30 \mathrm{~m}$ of the modelled sediment column is significantly modified by advection/diffusion processes. Since this is a first order estimate, we empirically tested the required model height, that is, the sediment height over which tracer concentrations were significantly influenced during a $20 \mathrm{Kyr}$ simulation. In fact, adopting a very long sedimentary column insures that the boundary condition (fixed tracers value at the modelled sedimentary column base) does not influence advection and diffusion of tracers in the upper part of the modelled profile.

\subsection{Origin of interstitial water advection}

The positive value for $v_{0}$ physically corresponds to an upward advection of water through the sediment column, induced from below, and is distinctly different from the water flux due to sediment compaction during burial, which arises from a porosity decrease. At the coring location, $v_{0}$ is very small $(0.035 \mathrm{~mm} / \mathrm{yr})$ but plays a significant role in the diffusion/advection model since over a modelling duration of $20 \mathrm{Kyr}$, it transports solutes from below to a height over $\sim 7 \mathrm{~m}$.

Advection of water in marine sediments may be caused by multiple processes. For example, changes in the heat gradient (which induces thermal expansion of interstitial water) as well as the diagenetic alteration of clays at great depths (which releases water) (Boles and Franks, 1979) may induce small interstitial overpressure that may lead to a small upward motion in the interstitial fluid. However, for our case in this study, the driving process cannot be firmly constrained with the available data. Such small advection was also reported within the sediment of the Black Ridge (U.S. Atlantic passive margin), but its origin was also unknown (Egeberg and Dickens, 1999).

\subsection{The isolated Black Sea: a giant fresh water lake?}

Many observations like drowned coastal and alluvial features, and erosional unconformities on continental shelves, support the existence of low-stands (e.g. Aksu et al., 2002b; Görür et 
al., 2001; Kaplin and Selivanov, 2004; Lericolais et al., 2007, 2009; Popescu et al., 2004; Ryan et al., 1997, 2003). Although not well dated (Popescu et al., 2004), the lowest level, approximately $100 \mathrm{~m}$ below present, seemed to have occurred around the Last Glacial Maximum. As a consequence, during the Last Glacial Maximum, the coring site was approximately $250 \mathrm{mbsl}$ (today $\sim 350 \mathrm{mbsl}$ ). Therefore our conclusions, $\mathrm{S}_{\mathrm{LGM}}(1 \pm 0.35 \mathrm{psu})$ and $\delta^{18} \mathrm{O}_{\mathrm{LGM}}(-10.1 \pm 0.2 \%$ ), clearly suggest that the Black Sea "Lake" was a freshwater body at least in the upper $250 \mathrm{~m}$. Recent studies (Bahr et al., 2006; Kwiecien et al., 2008, 2009) have suggested that the entire Black Sea "Lake" water column would have been uniform on the basin scale prior to ca $14.5 \mathrm{ka}$ calBP. In fact, stable oxygen isotopic records from a core transect along the NW Black Sea slope, spanning depths from 200 to $2000 \mathrm{mbsl}$ (Bahr et al., 2006), show exactly the same pattern as those recorded from a core recovered in the SW Black Sea (Kwiecien et al., 2009) both in trend and in amplitude until $14.5 \mathrm{ka}$ calBP. Furthermore, the reservoir age of the Black Sea "Lake" has been homogeneous in depth until $14.5 \mathrm{ka}$ calBP (Kwiecien et al., 2008). All of these observations strongly suggest that the Black Sea "Lake" was a homogeneous freshwater body since the LGM, until at least $14.5 \mathrm{ka}$ calBP.

However, a few previous studies contradict our results and interpretations. Using an approach similar to ours, Manheim and Chan (1974) found that bottom Black Sea "Lake" salinity was around 6 psu. Since the value of Manheim and Chan (1974) was inferred from chloride profiles restricted to the top $8 \mathrm{~m}$ of sediment, in Figure 7A, we show that, at our coring site, the top $8 \mathrm{~m}$ of sediment may have only preserved recent variations in chlorinity which cannot help to constrain glacial variations, suggesting that the lack of chloride content data at greater depths in the sediment may have led Manheim and Chan (1974) to overestimate the bottom salinity of the "Black Sea" Lake by approximately $5 \mathrm{psu}$.

Several studies based on dynocyst fossil assemblages have estimated the surface salinity of the Black Sea "Lake" to a range from 7 to 12 psu (e.g. Marret et al., 2009; Mudie et al., 2001, 2002b). However, for the moment, robust constraints on ecological affinities do not appear to exist for dinocyst assemblages in the Black Sea "Lake" (Marret et al., 2004). Spiniferites cruciformis, a dinoflagellate cyst, was described for the first time in glacial sediments of the Black Sea, and had been initially considered as apparently adapted to low salinity environments (Wall et al., 1973). Later, this dinoflagellate was found in late glacial to Holocene sediments from the Marmara Sea (Mudie et al., 2001), which was a brackish lake (Zitter et al., 2008) until approximately 14.7 ka calBP (Vidal et al., 2010). S. cruciformis has been found in sediments from the brackish Aral Sea (Sorrel et al., 2006) as well, and even from freshwater Lake Kastoria (Kouli et al., 2001). Most recently, S. cruciformis has been found in modern sediment from the brackish Caspian Sea (Marret et al., 2004), suggesting that it is tolerant in a wide range of salinities. Moreover, this taxon shows extreme morphological variability (Mudie et al., 2001; Wall et al., 1973). Such variability may be linked to fluctuations in salinity (Dale, 1996). However, no clear relationship between the different morphotypes and surface salinity has been established (Kouli et al., 2001; Mudie et al., 2001).

If these estimates based on dinocyst assemblages are correct, discrepancies with our results may be explained by an increase in salinity due to the evaporative condition that has occurred in the Black Sea "Lake" since approximately 14.5 ka calBP (eg.Bahr et al., 2006, 2008). Therefore, we tested the validity of surface salinity estimates inferred from dinocyst assemblages (7 to $12 \mathrm{psu}$ ) with our modelling procedure by increasing the bottom water salinity from 1 to $7-12$ psu after 14.5 ka calBP. Utilized values were actually the minimum ones for bottom waters since water density is mainly driven by salinity, and since bottom waters have always been at least as saline as surface waters (further explanations are available in Figure 7B). Using these alternative scenarios, modelled salinity profiles move away from measured one (Figure 7B).

Sensitivity tests reinforced our result that the Black Sea "Lake" was a freshwater lake during the LGM, until the last reconnection dated to $\sim 9$ ka calBP. 


\subsection{Hydrologic conditions since the last reconnection}

\subsubsection{Scenarios of reconnection}

Both "Outflow" and "Flood" scenarios lead to simulated present day profiles which similarly fit measurements for the same range for vertical advection $\left(\mathrm{v}_{0}\right)$ of $35 \pm 10 \mathrm{~cm} / \mathrm{Kyr}$ (Figure 6A\&B; Figure $4 \mathrm{~A} \& B$ ), indicating that these measurements do not allow us to distinguish between both hypotheses for reconnections in the Black Sea. The reason is that during the $\sim 9 \mathrm{ka}$ following reconnection, the hydrologic impacts of the reconnection were lost by diffusion.

\subsubsection{Hydrologic equilibrium of the Black Sea restricted to the last $2 \mathrm{kyr}$}

The salinity scenarios leading to the "present day" simulated profiles that best fit the measurements predicted that the Black Sea reached its modern salinity level at $2 \pm 0.5 \mathrm{ka}$ calBP, several millennia after reconnecting with the global ocean (Figure 4), suggesting that the Black Sea was in hydrologic equilibrium for only the last 1500 to 2500 years. A well known sedimentary marker is the final invasion of Emiliania huxleyi, which is generally interpreted as the onset of modern Black Sea hydrologic conditions (Giunta et al., 2007). The age of this time marker is ca $2000 \mathrm{yr}$ calBP (Lamy et al., 2006), in very good agreement with our estimations. Therefore, salinization of the basin took place very slowly during ca $7000 \mathrm{yr}$, likely due to the large volume of the Black Sea and river inflows that may have been larger than today. In fact, the salty Marmara Sea water intrusion occurred during a period of increased precipitation in the region (9-3 ka calBP) (Borisova et al., 2006; Feurdean et al., 2008; Jones et al., 2007; Mudie et al., 2002a; Sperling et al., 2003). Using steady hydraulic considerations, Lane-Serff et al. (1997) concluded that from river inputs feeding the Black Sea twice as much as today $\left(20000 \mathrm{~m}^{3} / \mathrm{s}\right)$, complete salinization would have been achieved within approximately $5 \mathrm{kyr}$, in good agreement with our results.

\section{Conclusion}

Our results strongly suggest that, during the last glacial period, the Black Sea "Lake" was a fresh and ${ }^{18} \mathrm{O}$-depleted water body. Freshwater would have allowed Neolithic farming on ancient exposed Black Sea shelves. Our data did not allow us to finely characterize the rate of refilling for the Black Sea "Lake" during its last reconnection with the Mediterranean Sea. After the last reconnection, the salinity of the Black Sea reached its current value of $\sim 2000 \mathrm{yr}$ calBP, in good agreement with the onset of modern Black Sea hydrologic conditions (Unit I deposition). Higher precipitation in the Black Sea drainage area during the Early Holocene could explain such a long time of salinization.

\section{Acknowledgements}

Our paper is a contribution to the ASSEMBLAGE project funded by the European Commission (EVK3-CT-2002-00090). We thank the crew of the research vessel Marion Dufresne for its assistance during the ASSEMBLAGE 1 cruise. We also thank G. Leduc, Y. Ternois, and $\mathrm{F}$. Ebersbach for on board pore water sampling. We are also grateful to $\mathrm{N}$. Çagatay who provided the pore water sediment squeezer. M.E. Böttcher wishes to thank A. Schipper and the Max Plank Society for technical and financial support, respectively. We also thank anonymous reviewers for their constructive comments. 


\section{References}

Adkins, J.F., Schrag, D.P., 2003. Reconstructing Last Glacial Maximum bottom water salinities from deep-sea sediment pore fluid profiles. Earth and Planetary Science Letters 216, 109-123.

Aksu, A., Hiscott, R.N., Mudie, P., Rochon, A., Kaminski, M.A., Abrajano, T., Yasar, D., 2002a. Persistent Holocene outflow from the Black Sea to the Eastern Mediterranean contradicts Noah's Flood hypothesis. GSA Today 12, 4-10.

Aksu, A.E., Hiscott, R.N., Yasar, D., Isler, F.I., Marsh, S., 2002b. Seismic stratigraphy of Late Quaternary deposits from the southwestern Black Sea shelf: evidence for non-catastrophic variations in sea-level during the last $\sim 10000 \mathrm{yr}$. Marine Geology 190, 61-94.

Arz, H., Lamy, F., Kwiecien, O., Dulski, P., Röhl, U., 2008. Holocene and Eemian sapropel sedimentation in the anoxic basin of the Black Sea. Geophysical Research Abstracts 10, 07288.

Bahr, A., Arz, H.W., Lamy, F., Wefer, G., 2006. Late glacial to Holocene paleoenvironmental evolution of the Black Sea, reconstructed with stable oxygen isotope records obtained on ostracod shells. Earth and Planetary Science Letters 241, 863-875.

Bahr, A., Lamy, F., Arz, H.W., Major, C., Kwiecien, O., Wefer, G., 2008. Abrupt changes of temperature and water chemistry in the late Pleistocene and early Holocene Black Sea. Geochem. Geophys. Geosyst. 9, Q01004, doi: 10.1029/2007GC001683.

Ballard, R.D., Coleman, D.F., Rosenberg, G.D., 2000. Further evidence of abrupt Holocene drowning of the Black Sea shelf. Marine Geology 170, 253-261.

Berner, R.A., 1980. Early Diagenesis - A Theorical Approach. Princeton University Press.

Boles, J.R., Franks, S.G., 1979. Clay diagenesis in Wilcox sandstones of southwest Texas: Implication of smectite diagenesis on sandstone cementation. Journal of Sedimentary Petrology 49, 55-70.

Borisova, O., Sidorchuk, A., Panin, A., 2006. Palaeohydrology of the Seim River basin, MidRussian Upland, based on palaeochannel morphology and palynological data. CATENA 66, 53-73.

Boudreau, B.P., 1997. Diagenetic Models and Their Implementation. Springer, Berlin.

Boudreau, B.P., Meysman, F.J.R., 2006. Predicted tortuosity of muds. Geology 34, 693-696.

Bruyevich, S.V., 1952. Increasingly fresh waters under recent sediments of the Black Sea. Akademii Nauk SSSR Doklady 84, 575-577.

Cox, R.A., Culkin, F., Riley, J.P., 1967. The electrical conductivity/chlorinity relationship in natural sea water. Deep Sea Research and Oceanographic Abstracts 14, 203-220.

Dale, B., 1996. Dinoflagellate cyst ecology: modelling and geological applications, In: Jansonius, J., McGregor, D.C. (Eds.), Palynology: Principles and Applications. American Association of Stratigraphic Palynologists Foundation, Dallas TX, pp. 1249-1275. 
Egeberg, P.K., Dickens, G.R., 1999. Thermodynamic and pore water halogen constraints on gas hydrate distribution at ODP Site 997 (Blake Ridge). Chemical Geology 153, 53-79.

Feurdean, A., Klotz, S., Mosbrugger, V., Wohlfarth, B., 2008. Pollen-based quantitative reconstructions of Holocene climate variability in NW Romania. Palaeogeography, Palaeoclimatology, Palaeoecology 260, 494-504.

Giunta, S., Morigi, C., Negri, A., Guichard, F., Lericolais, G., 2007. Holocene biostratigraphy and paleoenvironmental changes in the Black Sea based on calcareous nannoplankton. Marine Micropaleontology 63, 91-110.

Görür, N., Çagatay, M.N., Emre, Ö., Alpar, B., Sakıç, M., Islamoglu, Y., Algan, O., Erkal, T., Keçer, M., Akkök, R., Karllk, G., 2001. Is the abrupt drowning of the Black Sea shelf at 7150 yr a myth? Marine Geology 176, 65-73.

Hiscott, R.N., Aksu, A.E., Mudie, P.J., Marret, F., Abrajano, T., Kaminski, M.A., Evans, J., Çakiroglu, A.I., Yasar, D., 2007. A gradual drowning of the southwestern Black Sea shelf: Evidence for a progressive rather than abrupt Holocene reconnection with the eastern Mediterranean Sea through the Marmara Sea Gateway. Quaternary International 167-168, 19-34.

Jenden, P., Gieskes, J.M., 1983. Chemical and isotopic composition of interstitial water from Deep Sea Drilling Project Sites 533 and 534, In: Sheridan, R.E., Gradstein, F.M. et al. (Eds.), Initial Reports Deep Sea Drilling Project. US Government Printing Office, Washington, pp. 453-461.

Jones, M.D., Roberts, C.N., Leng, M.J., 2007. Quantifying climatic change through the last glacial-interglacial transition based on lake isotope palaeohydrology from central Turkey. Quaternary Research 67, 463-473.

Jørgensen, B.B., Böttcher, M.E., Lüschen, H., Neretin, L.N., Volkov, I.I., 2004. Anaerobic methane oxidation and a deep $\mathrm{H}_{2} \mathrm{~S}$ sink generate isotopically heavy sulfides in Black Sea sediments. Geochimica et Cosmochimica Acta 68, 2095-2118.

Jørgensen, B.B., Weber, A., Zopfi, J., 2001. Sulfate reduction and anaerobic methane oxidation in Black Sea sediments. Deep Sea Research Part I: Oceanographic Research Papers 48, 2097-2120.

Kaplin, P.A., Selivanov, A.O., 2004. Lateglacial and Holocene sea level changes in semienclosed seas of North Eurasia: examples from the contrasting Black and White Seas. Palaeogeography, Palaeoclimatology, Palaeoecology 209, 19-36.

Kouli, K., Brinkhuis, H., Dale, B., 2001. Spiniferites cruciformis: a fresh water dinoflagellate cyst? Review of Palaeobotany and Palynology 113, 273-286.

Kwiecien, O., Arz, H., Lamy, F., Wulf, S., Bahr, A., Röhl, U., Haug, G.H., 2008. Estimated reservoir ages of the Black Sea since the last glacial. Radiocarbon 50, 99-118.

Kwiecien, O., Arz, H.W., Lamy, F., Plessen, B., Bahr, A., Haug, G.H., 2009. North Atlantic control on precipitation pattern in the eastern Mediterranean/Black Sea region during the last glacial. Quaternary Research 71, 375-384.

Lambeck, K., Sivan, D., Purcell, A., 2007. Timing of the last Mediterranean Sea - Black Sea connection from isostatic models and regional sea-level data, In: Yanko-Hombach, V.V., 
Gilbert, A.S., Panin, N. (Eds.), The Black Sea Flood Question: Change in Coastline, Climate and Human Settlement. Springer, Heidelberg, pp. 797-808.

Lamy, F., Arz, H.W., Bond, G.C., Bahr, A., Pätzold, J., 2006. Multicentennial-scale hydrological changes in the Black Sea and northern Red Sea during the Holocene and the Arctic/North Atlantic Oscillation. Paleoceanography 21, PA1008, doi: 10.1029/2005PA001184.

Lane-Serff, G.F., Rohling, E.J., Bryden, H.L., Charnock, H., 1997. Postglacial Connection of the Black Sea to the Mediterranean and its Relation to the Timing of Sapropel Formation. Paleoceanography 12, 169-174.

Lericolais, G., Bulois, C., Gillet, H., Guichard, F., 2009. High frequency sea level fluctuations recorded in the Black Sea since the LGM. Global and Planetary Change 66, 65-75.

Lericolais, G., Popescu, I., Guichard, F., Popescu, S.M., 2007. A Black Sea lowstand at 8500 $\mathrm{yr}$ B.P. indicated by a relict coastal dune system at a depth of $90 \mathrm{~m}$ below sea level. Geological Society of America Special Papers 426, 171-188.

Luff, R., Wallmann, K., 2003. Fluid flow, methane fluxes, carbonate precipitation and biogeochemical turnover in gas hydrate-bearing sediments at Hydrate Ridge, Cascadia Margin: numerical modeling and mass balances. Geochimica et Cosmochimica Acta 67, 3403-3421.

Major, C., Ryan, W., Lericolais, G., Hajdas, I., 2002. Constraints on Black Sea outflow to the Sea of Marmara during the last glacial-interglacial transition. Marine Geology 190, 19-34.

Major, C.O., Goldstein, S.L., Ryan, W.B.F., Lericolais, G., Piotrowski, A.M., Hajdas, I., 2006. The co-evolution of Black Sea level and composition through the last deglaciation and its paleoclimatic significance. Quaternary Science Reviews 25, 2031-2047.

Manheim, F.T., Chan, K.M., 1974. Interstitial waters of Black Sea sediments: new data and review, In: Degens, E.T., Ross, D.A. (Eds.), The Black Sea: Geology, Chemistry, and Biology. American Association of Petroleum Geologists, Tulsa, pp. 155-180.

Manheim, F.T., Schug, D.M., 1978. Interstitial waters of Black Sea cores, In: Ross, D.A., Neprochnov, Y.P. et al. (Eds.), Initial Reports of the Deep Sea Drilling Project. U.S. Government Printing Office, Washington, pp. 637-651.

Marret, F., Leroy, S., Chalié, F., Gasse, F., 2004. New organic-walled dinoflagellate cysts from recent sediments of Central Asian seas. Review of Palaeobotany and Palynology 129, 1-20.

Marret, F., Mudie, P., Aksu, A., Hiscott, R.N., 2009. A Holocene dinocyst record of a two-step transformation of the Neoeuxinian brackish water lake into the Black Sea. Quaternary International 197, 72-86.

Mudie, P.J., Aksu, A.E., Yasar, D., 2001. Late Quaternary dinoflagellate cysts from the Black, Marmara and Aegean seas: variations in assemblages, morphology and paleosalinity. Marine Micropaleontology 43, 155-178.

Mudie, P.J., Rochon, A., Aksu, A.E., 2002a. Pollen stratigraphy of Late Quaternary cores from Marmara Sea: land-sea correlation and paleoclimatic history. Marine Geology 190, 233260. 
Mudie, P.J., Rochon, A., Aksu, A.E., Gillespie, H., 2002b. Dinoflagellate cysts, freshwater algae and fungal spores as salinity indicators in Late Quaternary cores from Marmara and Black seas. Marine Geology 190, 203-231.

Myers, P.G., Wielki, C., Goldstein, S.B., Rohling, E.J., 2003. Hydraulic calculations of postglacial connections between the Mediterranean and the Black Sea. Marine Geology 201, 253-267.

Naudts, L., Greinert, J., Artemov, Y., Staelens, P., Poort, J., Van Rensbergen, P., De Batist, M., 2006. Geological and morphological setting of 2778 methane seeps in the Dnepr paleodelta, northwestern Black Sea. Marine Geology 227, 177-199.

Özsoy, E., Rank, D., Salihoglu, I., 2002. Pycnocline and Deep Mixing in the Black Sea: Stable Isotope and Transient Tracer Measurements. Estuarine, Coastal and Shelf Science 54, 621-629.

Özsoy, E., Ünlüata, Ü., 1997. Oceanography of the Black Sea: A review of some recent results. Earth-Science Reviews 42, 231-272.

Paul, H.A., Bernasconi, S.M., Schmid, D.W., McKenzie, J.A., 2001. Oxygen isotopic composition of the Mediterranean Sea since the Last Glacial Maximum: constraints from pore water analyses. Earth and Planetary Science Letters 192, 1-14.

Popescu, I., Lericolais, G., Panin, N., Normand, A., Dinu, C., Le Drezen, E., 2004. The Danube submarine canyon (Black Sea): morphology and sedimentary processes. Marine Geology 206, 249-265.

Rank, D., Özsoy, E., Salihoglu, I., 1999. Oxygen-18, deuterium and tritium in the Black Sea and the Sea of Marmara. Journal of Environmental Radioactivity 43, 231-245.

Reimer, P.J., Baillie, M.G.L., Bard, E., Bayliss, A., Beck, J.W., Blackwell, P.G., Bronk Ramsey, C., Buck, C.E., Burr, G.S., Edwards, R.L., Friedrich, M., Grootes, P.M., Guilderson, T.P., Hajdas, I., Heaton, T.J., Hogg, A.G., Hughen, K.A., Kaiser, K.F., Kromer, B., McCormac, G., Manning, S., Reimer, R.W., Richards, D.A., Southon, J.R., Talamo, S., Turney, C.S.M., van der Plicht, J., Weyhenmeyer, C.E., 2009. IntCal09 and Marine09 Radiocarbon Age Calibration Curves, 0-50,000 Years cal BP. Radiocarbon 51, 1111-1150.

Rösler, H.J., Lange, H.J., 1976. Geochemische Tabellen. Ferdinand Enke Verlag, Stuttgart.

Ryan, W.B.F., Major, C.O., Lericolais, G., Goldstein, S.L., 2003. Catastrophic Flooding of the Black Sea. Annual Review of Earth and Planetary Sciences 31, 525-554.

Ryan, W.B.F., Pitman, W.C., 1998. Noah's Flood: The New Scientific Discoveries about the Event that Changes History. Simon \& Schuster, New-York.

Ryan, W.B.F., Pitman, W.C., Major, C.O., Shimkus, K., Moskalenko, V., Jones, G.A., Dimitrov, P.,

Gorür, N., Sakinç, M., Yüce, H., 1997. An abrupt drowning of the Black Sea shelf. Marine Geology 138, 119-126.

Schrader, H.-J., 1979. Quaternary Paleoclimatology of the Black Sea basin. Sedimentary Geology 23, 165-180.

Schrag, D.P., DePaolo, D.J., 1993. Determination of $d^{18} O$ of Seawater in the Deep Ocean during the Last Glacial Maximum. Paleoceanography 8, 1-6. 
Schrag, D.P., Hampt, G., Murray, D.W., 1996. Pore Fluid Constraints on the Temperature and Oxygen Isotopic Composition of the Glacial Ocean. Science 272, 1930-1932.

Sorrel, P., Popescu, S.M., Head, M.J., Suc, J.P., Klotz, S., Oberhänsli, H., 2006. Hydrographic development of the Aral Sea during the last 2000 years based on a quantitative analysis of dinoflagellate cysts. Palaeogeography, Palaeoclimatology, Palaeoecology 234, 304-327.

Soulet, G., Ménot, G., Garreta, V., Rostek, F., Lericolais, G., Bard, E., in prep. Reservoir age changes of the Black Sea "Lake" through the Last Deglaciation: Paleoceanographic implications.

Sperling, M., Schmiedl, G., Hemleben, C., Emeis, K.C., Erlenkeuser, H., Grootes, P.M., 2003. Black Sea impact on the formation of eastern Mediterranean sapropel S1? Evidence from the Marmara Sea. Palaeogeography, Palaeoclimatology, Palaeoecology 190, 9-21.

Stoffers, P., Degens, E.T., Trimonis, E.S., 1978. Stratigraphy and suggested ages of Black Sea sediments cored during Leg 42B, In: Ross, D.A., Neprochnov, Y.P. et al. (Eds.), Initial Reports of the Deep Sea Drilling Project. U.S. Government Printing Office, Washington, pp. 483-488.

Vidal, L., Ménot, G., Joly, C., Bruneton, H., Rostek, F., Çagatay, M.N., Major, C., Bard, E., 2010. Hydrology in the Sea of Marmara during the last $23 \mathrm{ka}$ : Implications for timing of Black Sea connections and sapropel deposition. Paleoceanography 25, PA1205, doi: 10.1029/2009pa001735

Wall, D., Dale, B., Harada, K., 1973. Descriptions of new fossil dinoflagellates from the Late Quaternary of the Black Sea. Micropaleontology 19, 18-30.

Yanko-Hombach, V.V., 2007. Controversy over Noah's Flood in the Black Sea: geological and foraminiferal evidence from the shelf, In: Yanko-Hombach, V.V., Gilbert, A.S., Panin, N. (Eds.), The Black Sea Flood Question. Springer, Heidelberg, pp. 149-203.

Zitter, T.A.C., Henry, P., Aloisi, G., Delaygue, G., Çagatay, M.N., Mercier de Lepinay, B., AlSamir, M., Fornacciari, F., Tesmer, M., Pekdeger, A., Wallmann, K., Lericolais, G., 2008. Cold seeps along the main Marmara Fault in the Sea of Marmara (Turkey). Deep Sea Research Part I: Oceanographic Research Papers 55, 552-570.

Zubakov, V.A., 1988. Climatostratigraphic scheme of the Black Sea Pleistocene and its correlation with the oxygen-isotope scale and glacial events. Quaternary Research 29, 1-24. 


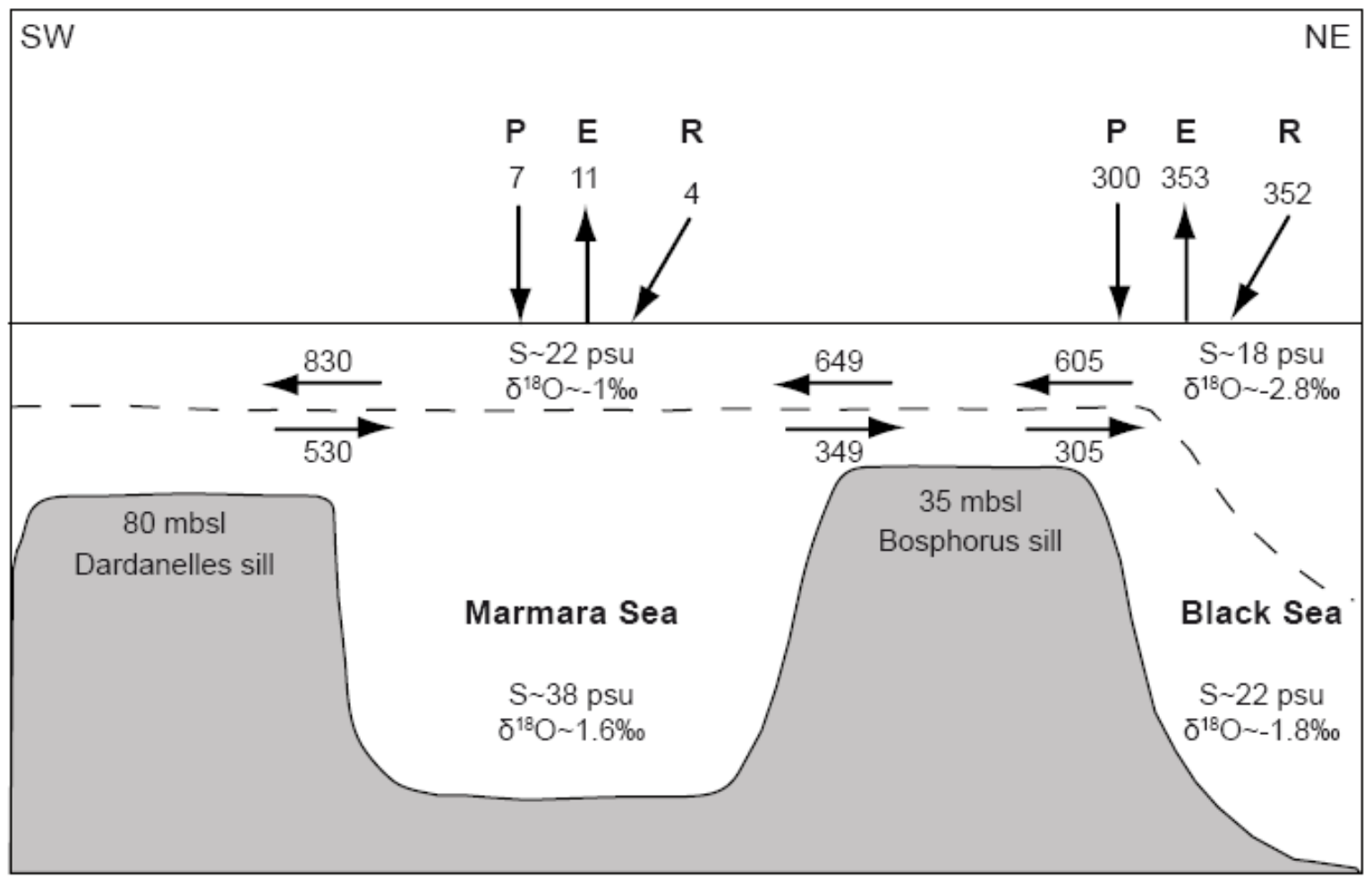

\section{Fiaure 1.}

Figure 1: The modern water exchange pattern in the Aegean - Marmara - Black Seas system. Numbers associated with the arrows are the mean annual water fluxes in $\mathrm{km}^{3} / \mathrm{yr}$, in the Turkish Straits System after Özsoy and Ünlüata (1997), as well as for precipitation (P), evaporation (E), and continental runoff $(R)$. Salinity $S$ and $\delta^{18} \mathrm{O}$ are, respectively, given in psu and in \% vs. SMOW (Özsoy and Ünlüata, 1997; Rank et al., 1999). 


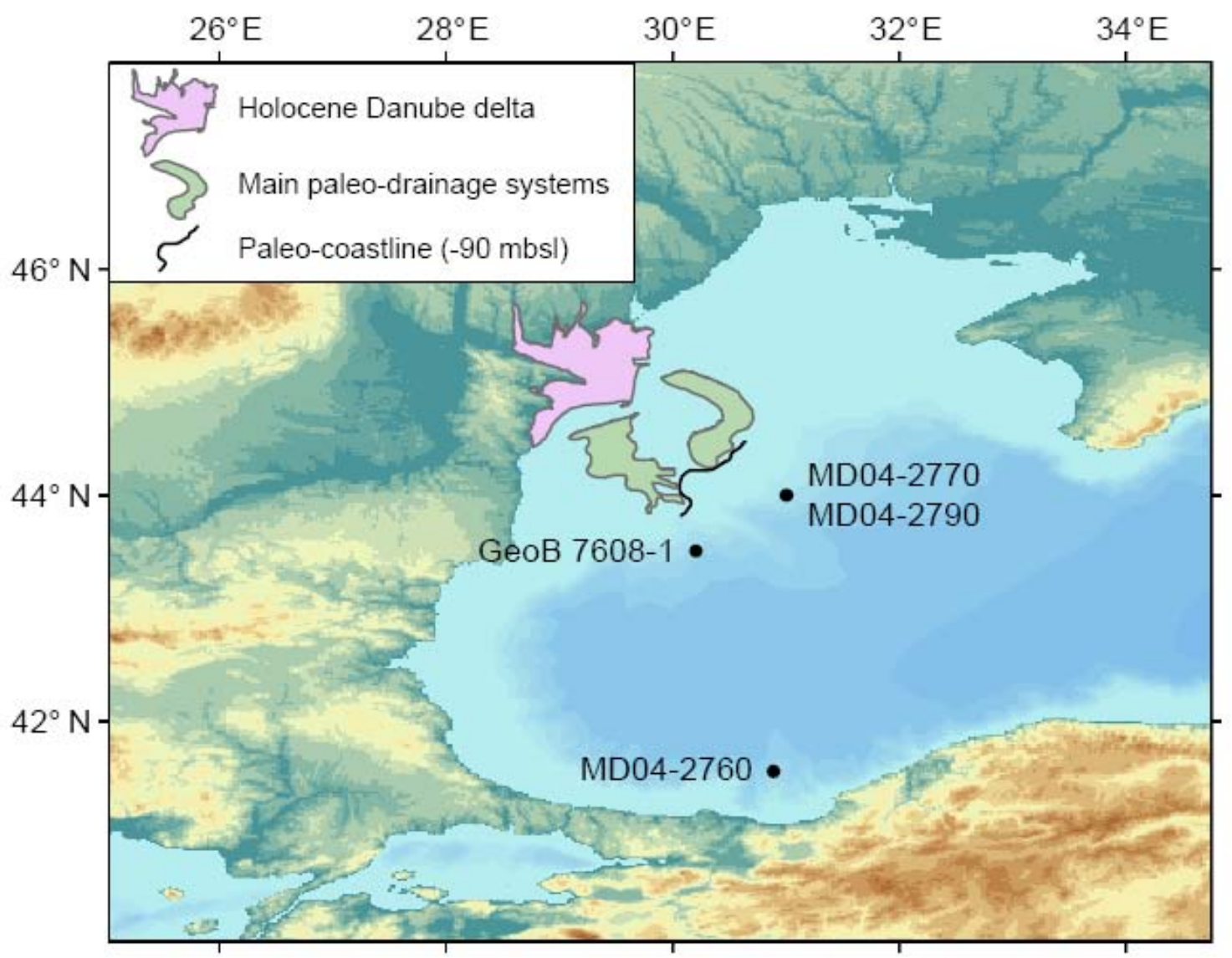

Figure 2

Figure 2: Location of the coring site. Are also shown coring sites of cores GeoB 7608-1 (Bahr et al., 2006) and MD04-2760 (Kwiecien et al., 2008). The map shows the Holocene Danube Delta, the main drainage systems of the glacial Danube, and the associated last glacial coastline from Popescu et al. (2004). 


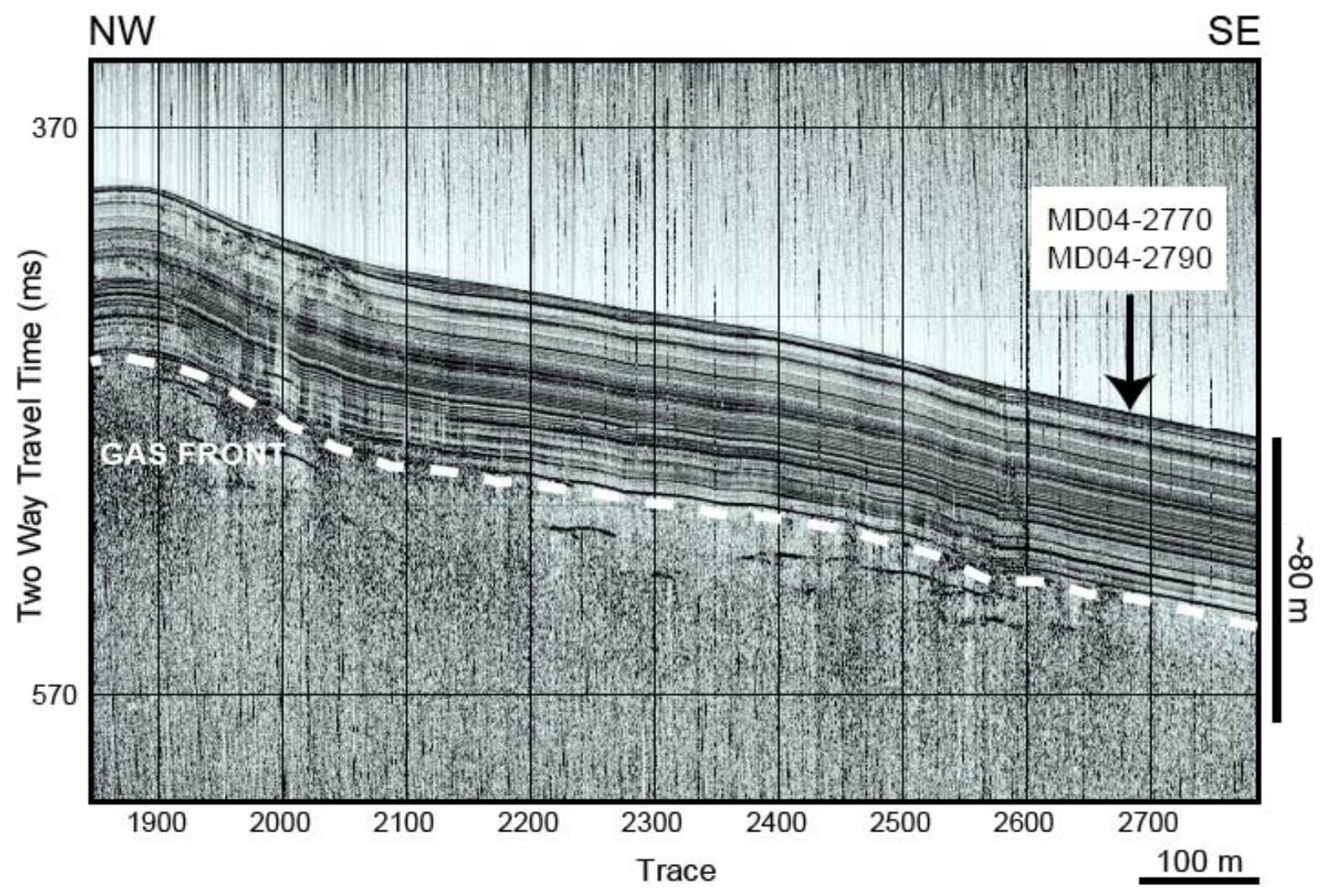

Figure 3.

Figure 3: The seismic profile (B2CH96, acquired in 2002 during the BlaSON2 cruise) of the coring site. The bold dashed white line represents the gas front. 
Age (ka cal BP)

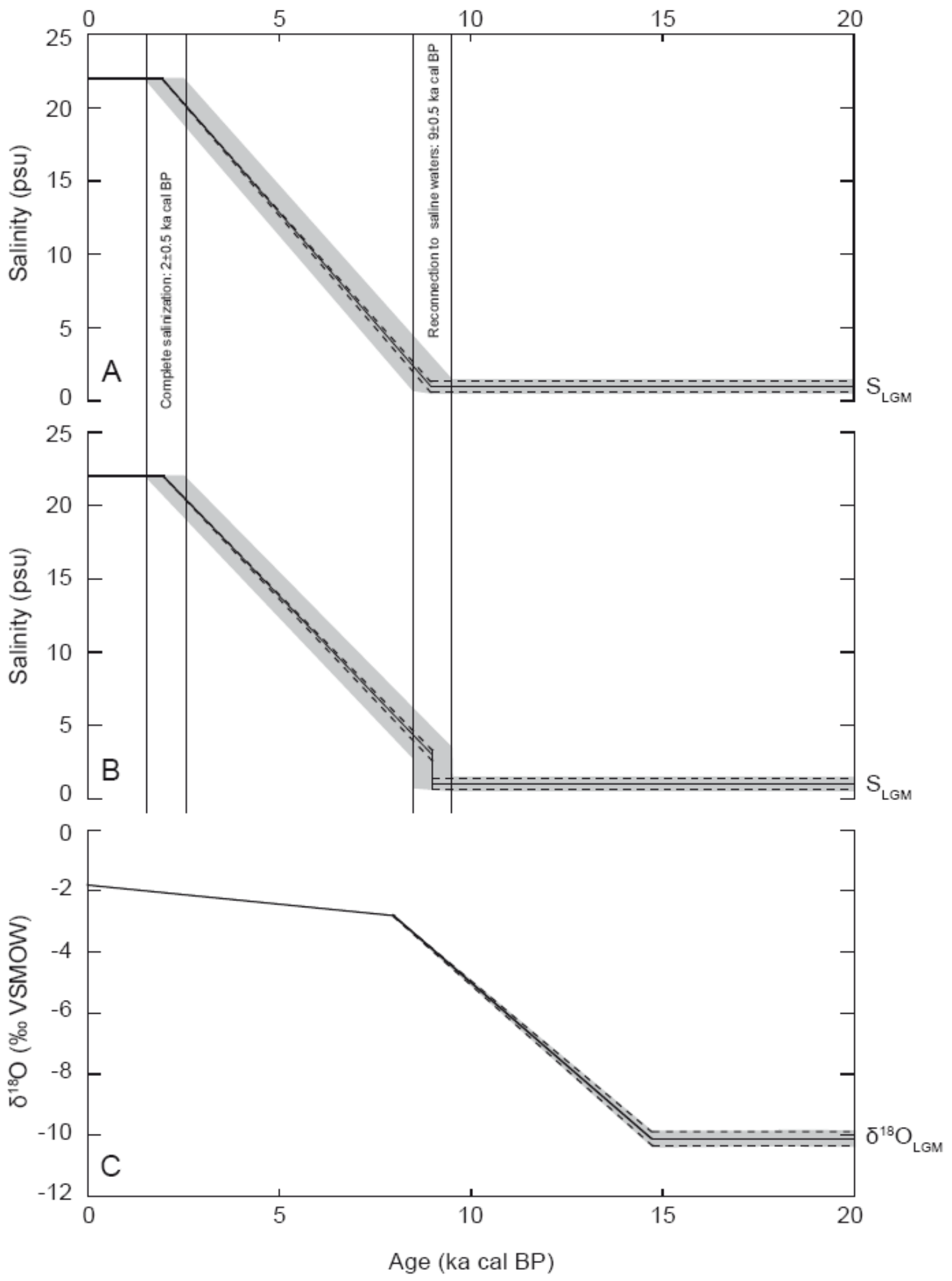

Figure 4. 
Figure 4: A \& B: Two ensembles of bottom water salinity change scenarios over the past 20 Kyr leading to modelled "present day" profiles that best fit the measured profile. Two different refilling conditions for the Black Sea "Lake" reconnection with the Marmara Sea were tested ("Outflow" vs. "Flood" hypotheses). C: Scenarios of $\delta^{18} \mathrm{O}$ evolution leading to modelled "present day" profiles which best fit the measured profile. Among the numerous tested scenarios, only scenarios which fulfilled the solution criteria of the modelling procedure (a minimal RMS and a similar value $v_{0}$ for $\left[\mathrm{Cl}^{-}\right]$and $\delta^{18} \mathrm{O}$ modelling, see $\S$ 2.3.3) are presented (the shaded area on each graph). The scenarios are shown as full and dashed black lines in $A, B$, and $C$ leading to the corresponding simulated profiles in Figure $6 A, B$, and $C$. 

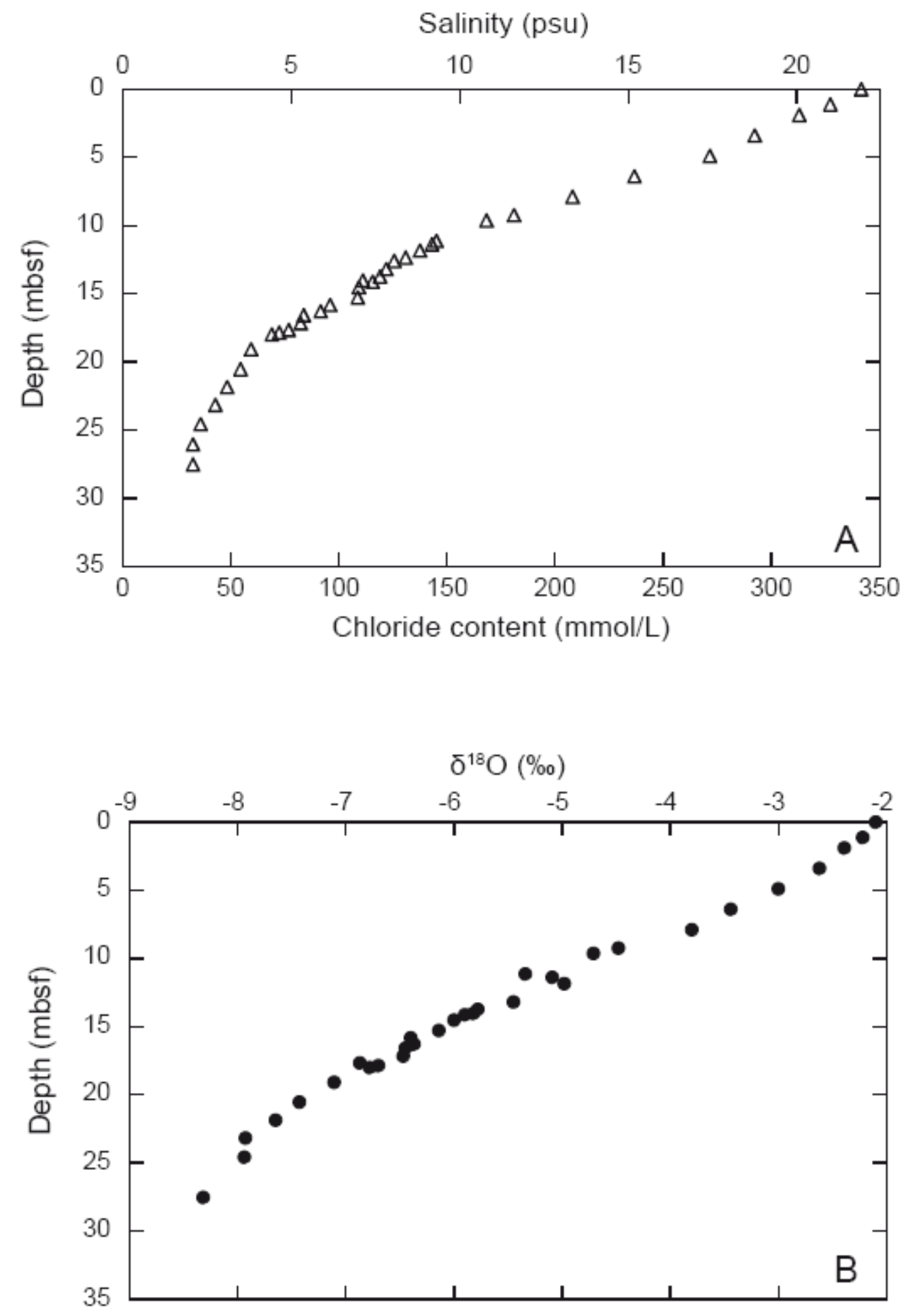

Figure 5.

Figure 5: Geochemical profiles measured in interstitial water from core MD04-2770. A: Black triangles represent the chloride content data $\left(\mathrm{mmol}^{\mathrm{L}} \mathrm{L}^{-1}\right)$ also presented in salinity practical 


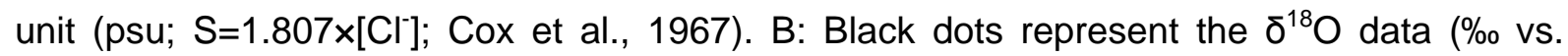
VSMOW). Depth is in meters below sea floor (mbsf). 
Salinity (psu)
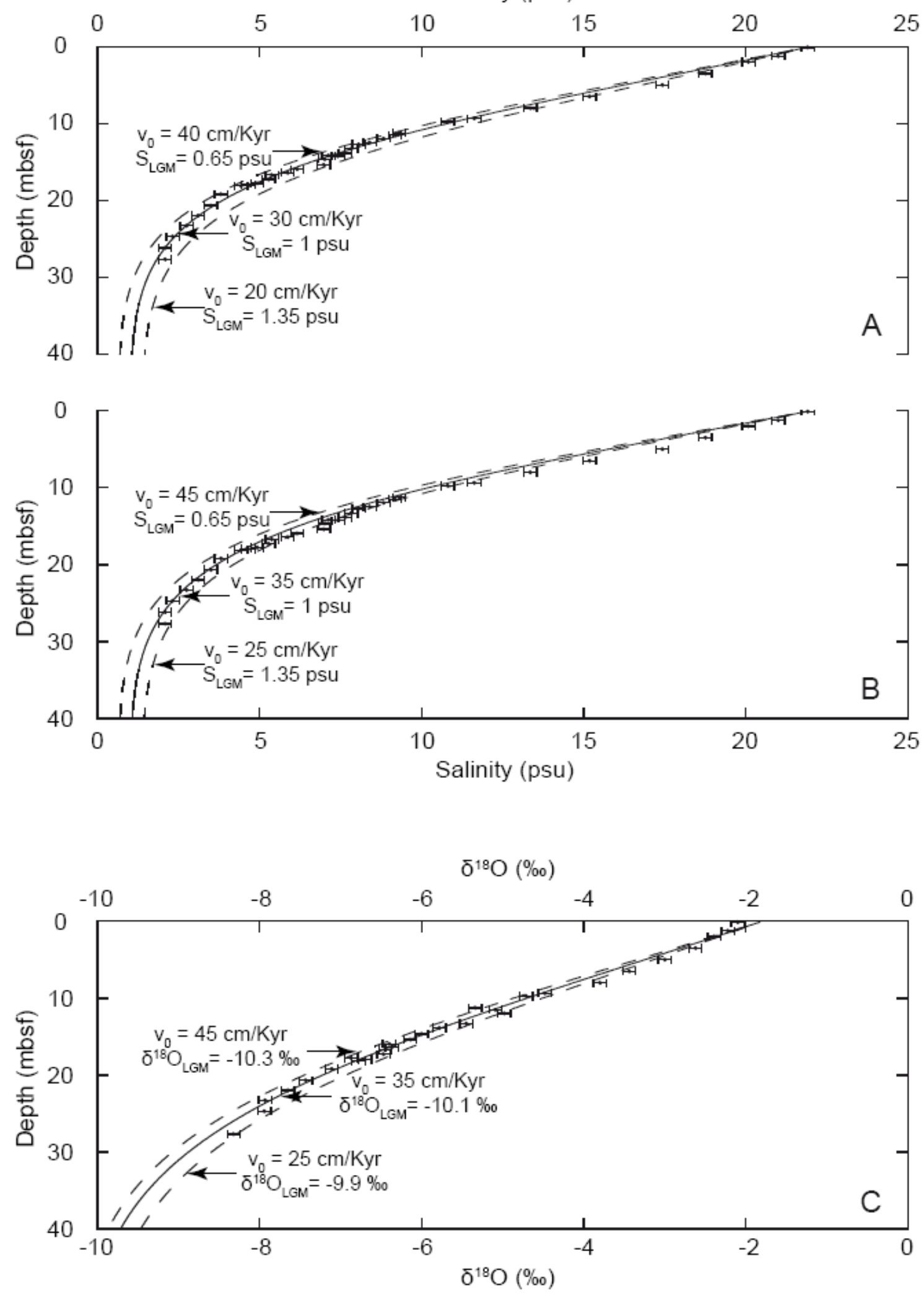

Figure 6.

Figure 6: "Present day" geochemical profiles in interstitial water simulated with bottom water scenarios shown with the same line pattern in Figure $4 A, B$, and $C$ (for different values of $v_{0}$ ). 
Black dots are salinity $(A$ and $B)$ and $\delta^{18} \mathrm{O}(\mathrm{C})$ measurements in interstitial water of sediment core MD04-2770 (same as in Figure 4), with error bars representing the analytical precision $(1 \sigma)$.
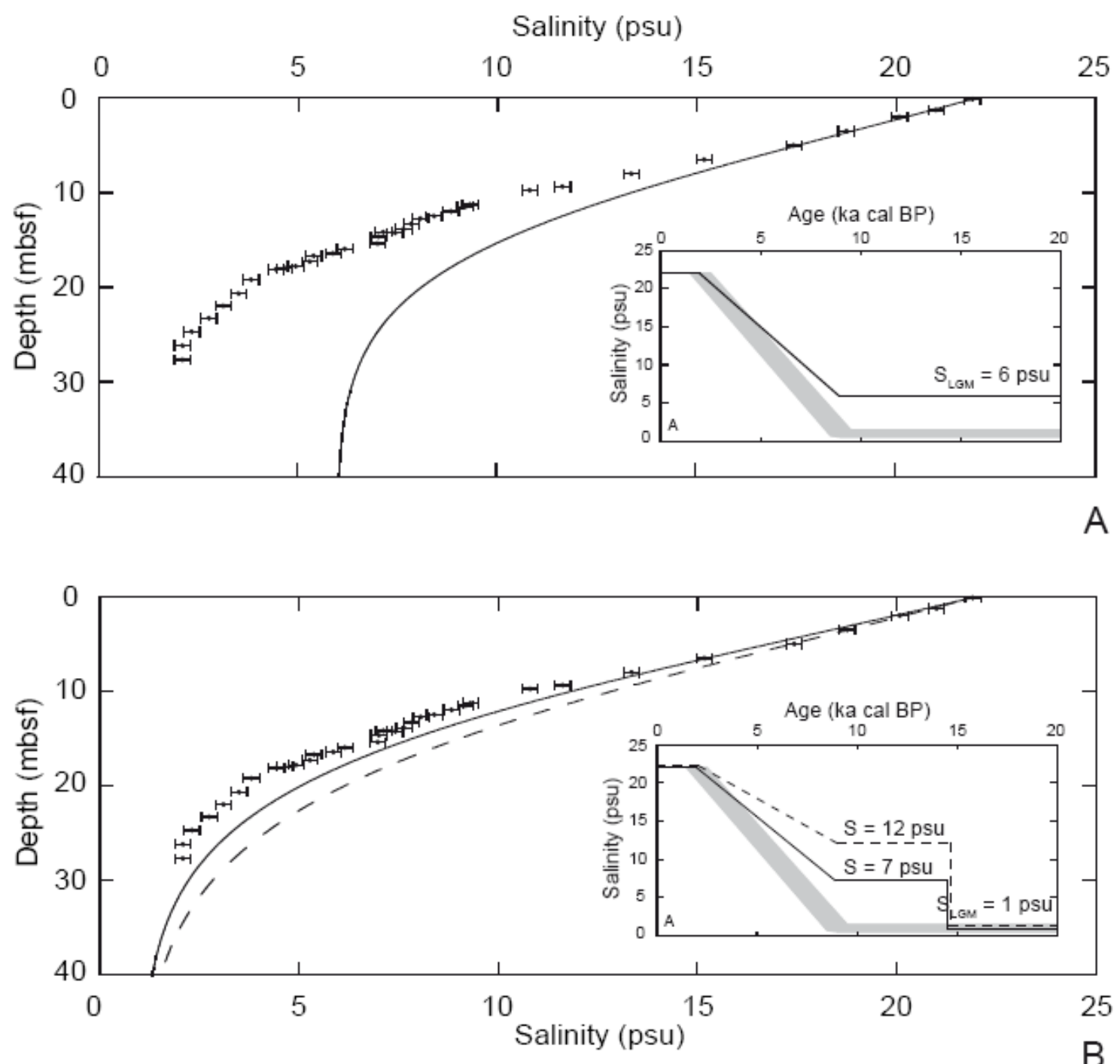

Figure 7.

Figure 7: Modelled present day salinity profiles (black lines) simulated for the alternative scenarios of salinity changes shown in inlay graphs, compared to the measured salinity data (black dots). Salinity scenarios were built as described in Figure 4A (shaded area) and were modified in order to test the following alternative hypotheses. A: $S_{L G M}$ was set to 6 psu instead of 1 psu in order to test the result of Manheim and Chan (1974). B: By assuming that the Black Sea "Lake" water column started to become stratified after the Bölling-Allerod (14.5 ka calBP; Bahr et al., 2006, 2008), the salinity was set to increase from a $S_{L G M}$ of 1 psu to 7 or $12 \mathrm{psu}$ (the black line and the black dashed line, respectively, in the inlay graph) as predicted by dinocyst assemblages (Mudie et al., 2001). In all simulations, $v_{0}$ was set to $35 \mathrm{~cm} / \mathrm{Kyr}$. 
Table 1. Estimations of Black Sea global average salinity after an instantaneous refilling of the Black Sea "Lake" ("Flood" Hypothesis)

\begin{tabular}{cccc}
\hline $\begin{array}{c}\text { "Flood" age } \\
\text { (ka BP) }\end{array}$ & $\begin{array}{c}\text { Approximate } \\
\text { global sea-level } \\
(\mathrm{mbsl})^{\mathrm{a}}\end{array}$ & $\begin{array}{c}\text { Maximum } \\
\text { inflowing water } \\
\text { volume }\left(\mathrm{Km}^{3}\right)\end{array}$ & $\begin{array}{c}\text { Black Sea } \\
\text { salinity } \\
\text { increase } \\
(\mathrm{psu})\end{array}$ \\
\hline 9.5 & -29 & 25800 & 1.8 \\
9 & -23 & 28340 & 2.0 \\
8.5 & -19 & 30030 & 2.1 \\
\hline
\end{tabular}

áLambeck et al. (2007)

Table 2: Interstitial water $\delta^{18} \mathrm{O}$ and chloride content of core MD04-2770

\begin{tabular}{ccc} 
Core depth $(\mathrm{cm})$ & $\delta^{18} \mathrm{O}(\%)$ & {$[\mathrm{Cl}]\left(\mathrm{mmol} . \mathrm{L}^{-1}\right)$} \\
\hline 0 & -2.10 & 342 \\
113 & -2.22 & 327 \\
190 & -2.39 & 313 \\
340 & -2.62 & 292 \\
490 & -3.00 & 272 \\
640 & -3.44 & 237 \\
790 & -3.80 & 208 \\
925 & -4.48 & 181 \\
964 & -4.71 & 168 \\
1114 & -5.34 & 145 \\
1139 & -5.09 & 143 \\
1185 & -4.98 & 138 \\
1235 & & 131 \\
1260 & & 126 \\
1320 & -5.45 & 122 \\
1375 & -5.78 & 119 \\
1404 & -5.82 & 111 \\
1414 & -5.90 & 116 \\
1453 & -6.00 & 109 \\
1528 & -6.14 & 108 \\
1583 & -6.40 & 96 \\
1629 & -6.37 & 92 \\
1659 & -6.45 & 84 \\
1717 & -6.47 & 82 \\
1767 & -6.87 & 77 \\
1787 & -6.70 & 73 \\
1801 & -6.78 & 69 \\
1909 & -7.11 & 59 \\
2054 & -7.43 & 55 \\
2186 & -7.65 & 48 \\
2317 & -7.93 & 43 \\
2458 & -7.94 & 36 \\
& &
\end{tabular}


Table 3. Ages of two lacustrian molluscs from cores retrieved during the 2004 Assemblage-1 cruise showing that the Black Sea was isolated at least since the last $50 \mathrm{ka}$ calBP.

\begin{tabular}{cccccccc}
\hline Core & $\begin{array}{c}\text { Water } \\
\text { depth }(\mathrm{m})\end{array}$ & $\begin{array}{c}\text { Sample } \\
\text { depth }(\mathrm{cm})\end{array}$ & $\begin{array}{c}\text { Sample } \\
\text { code }\end{array}$ & $\begin{array}{c}\text { Laboratory } \\
\text { code }\end{array}$ & $\begin{array}{c}\text { Dated } \\
\text { material }\end{array}$ & $\begin{array}{c}\text { Uncalibrated } \\
\text { AMS }{ }^{14} \text { C age } \\
(\mathrm{yr} \mathrm{BP}, \pm 1 \sigma)\end{array}$ & $\begin{array}{c}\text { Calibrated } \\
\text { age }^{\mathrm{b}}(\mathrm{yr} \mathrm{BP}, \pm \\
2 \sigma)\end{array}$ \\
\hline MD04-2753 & 63 & 1063 & FG-108 & POZ $^{\mathrm{a}}$ & Dreissena & $\begin{array}{c}42300 \pm \\
1100\end{array}$ & $46000 \pm 2100$ \\
\hline MD04-2754 & 453 & 1580 & FG-53 & POZ $^{\text {a }}$ & Turricaspia & $31000 \pm 400$ & $35600 \pm 800$ \\
\hline
\end{tabular}

${ }^{a}$ Poznan Radiocarbon Laboratory

${ }^{\mathrm{b}}$ calibrated to calendar age Reimer et al. (2009)

\section{References}

Bahr, A., Arz, H.W., Lamy, F., Wefer, G., 2006. Late glacial to Holocene paleoenvironmental evolution of the Black Sea, reconstructed with stable oxygen isotope records obtained on ostracod shells. Earth and Planetary Science Letters 241, 863-875.

Bahr, A., Lamy, F., Arz, H., Kuhlmann, H., Wefer, G., 2005. Late glacial to Holocene climate and sedimentation history in the NW Black Sea. Marine Geology 214, 309-322.

Bahr, A., Lamy, F., Arz, H.W., Major, C., Kwiecien, O., Wefer, G., 2008. Abrupt changes of temperature and water chemistry in the late Pleistocene and early Holocene Black Sea. Geochem. Geophys. Geosyst. 9, Q01004, doi: 10.1029/2007GC001683.

Kwiecien, O., Arz, H., Lamy, F., Wulf, S., Bahr, A., Röhl, U., Haug, G.H., 2008. Estimated reservoir ages of the Black Sea since the last glacial. Radiocarbon 50, 99-118.

Kwiecien, O., Arz, H.W., Lamy, F., Plessen, B., Bahr, A., Haug, G.H., 2009. North Atlantic control on precipitation pattern in the eastern Mediterranean/Black Sea region during the last glacial. Quaternary Research 71, 375-384.

Major, C., Ryan, W., Lericolais, G., Hajdas, I., 2002. Constraints on Black Sea outflow to the Sea of Marmara during the last glacial-interglacial transition. Marine Geology 190, 19-34.

Major, C.O., Goldstein, S.L., Ryan, W.B.F., Lericolais, G., Piotrowski, A.M., Hajdas, I., 2006. The coevolution of Black Sea level and composition through the last deglaciation and its paleoclimatic significance. Quaternary Science Reviews 25, 2031-2047.

Ross, D.A., Degens, E.T., 1974. Recent sediments of Black Sea, In: Degens, E.T., Ross, D.A. (Eds.), The Black Sea: Geology, Chemistry, and Biology. American Association of Petroleum Geologists, Tulsa, pp. 183-199.

Soulet, G., Ménot, G., Garreta, V., Rostek, F., Lericolais, G., Bard, E., in prep. Reservoir age changes of the Black Sea "Lake" through the Last Deglaciation: Paleoceanographic implications. 
A: Simplified descriptions of sister cores MD04-2770 \& MD04-2790 correlated with the common lithostratigraphic scheme for Late Quaternary Black Sea sediments (Ross and Degens, 1974). Depth is presented in meters below the sea floor (mbsf) and corresponds to corrected depths (i.e. excluding core gaps due to core retrieval).

B: Sedimentation rate variations are based on MD04-2790 age model (Soulet et al., in prep.), which also applies to sister core MD04-2770.

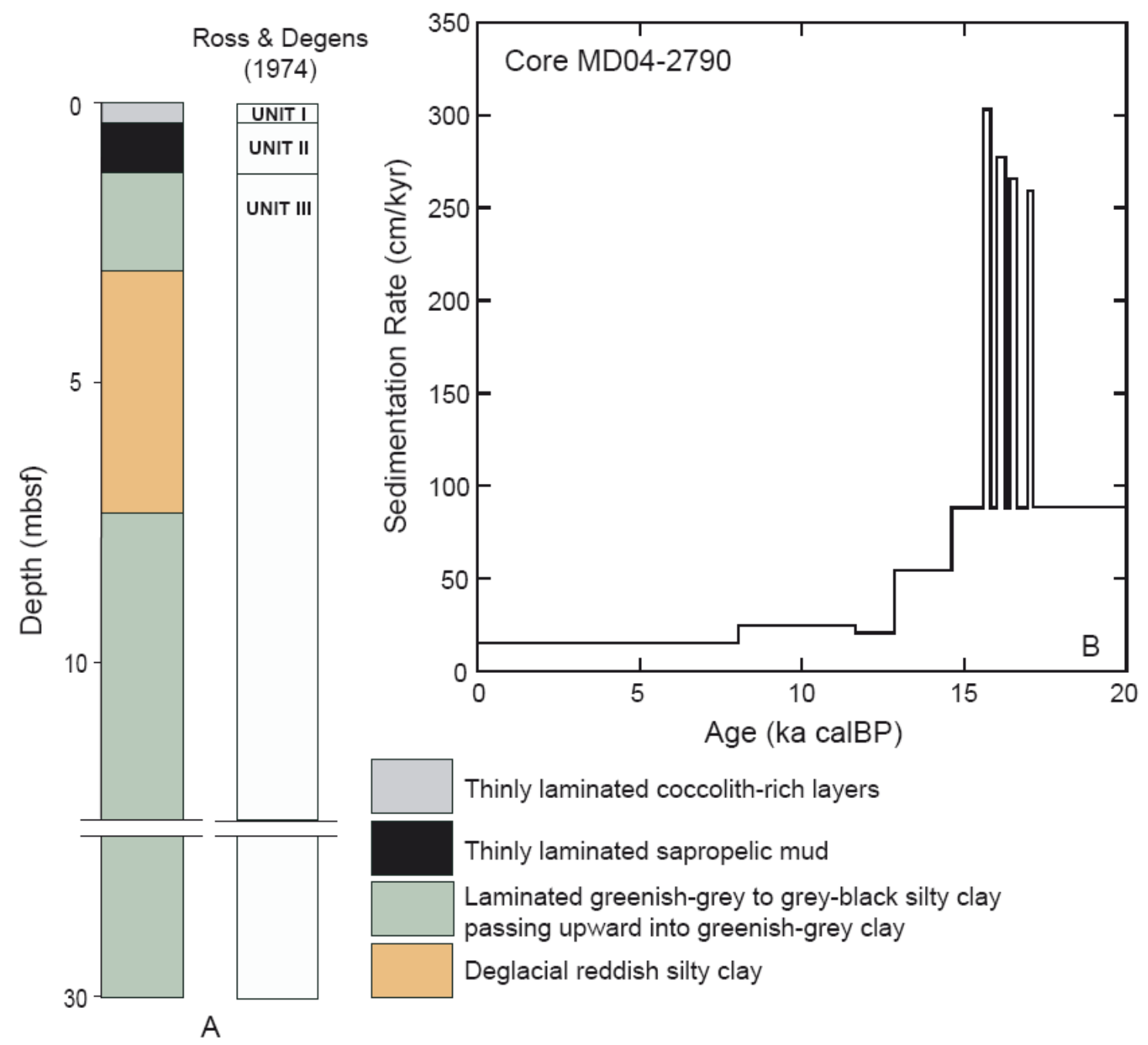

Appendix A

APPENDIX A

Core description and sedimentation rate

Long cores MD04-2770 and MD04-2790 are sister cores retrieved at exactly the same location. The two cores were retrieved using the Calypso giant piston corer of the research vessel Marion Dufresne. Fig. AA presents a simplified description of the two cores. Three units classically described for the Black Sea basin (Ross and Degens, 1974) are readily 
identified. Unit III from the base of the core $(\sim 30 \mathrm{~m})$ to $1.3 \mathrm{mbsf}$ represents the last lacustrine stage of the Black Sea (Neoeuxinian Lake). The unit is characterized by greenish-grey and grey-black silty clay, with very thin laminations passing upward to homogeneous greenish grey clay with the presence of black iron sulphide-enriched patches. The Red Layer interval which corresponds to deglacial pulses (Bahr et al., 2005, 2006, 2008; Kwiecien et al., 2008, 2009; Major et al., 2002, 2006) is present in both cores between 7.3 and 4.3 mbsf. The sapropelic Unit II (1.3 to $0.4 \mathrm{mbsf}$ ) is characterized by a dark olive green to dark brown thinly laminated mud. Unit I (0.4 mbsf to top) is characterized by thin coccolith-rich layers. Units II and I represent the last Black Sea marine stage.

The sedimentation rate (Fig. AB) was calculated from the age model of core MD042790. A complete description of the age model is in preparation (Soulet et al., in prep.). As we explained in Section 4.1.2, sedimentation has a minor influence on simulated interstitial water chemistry. 


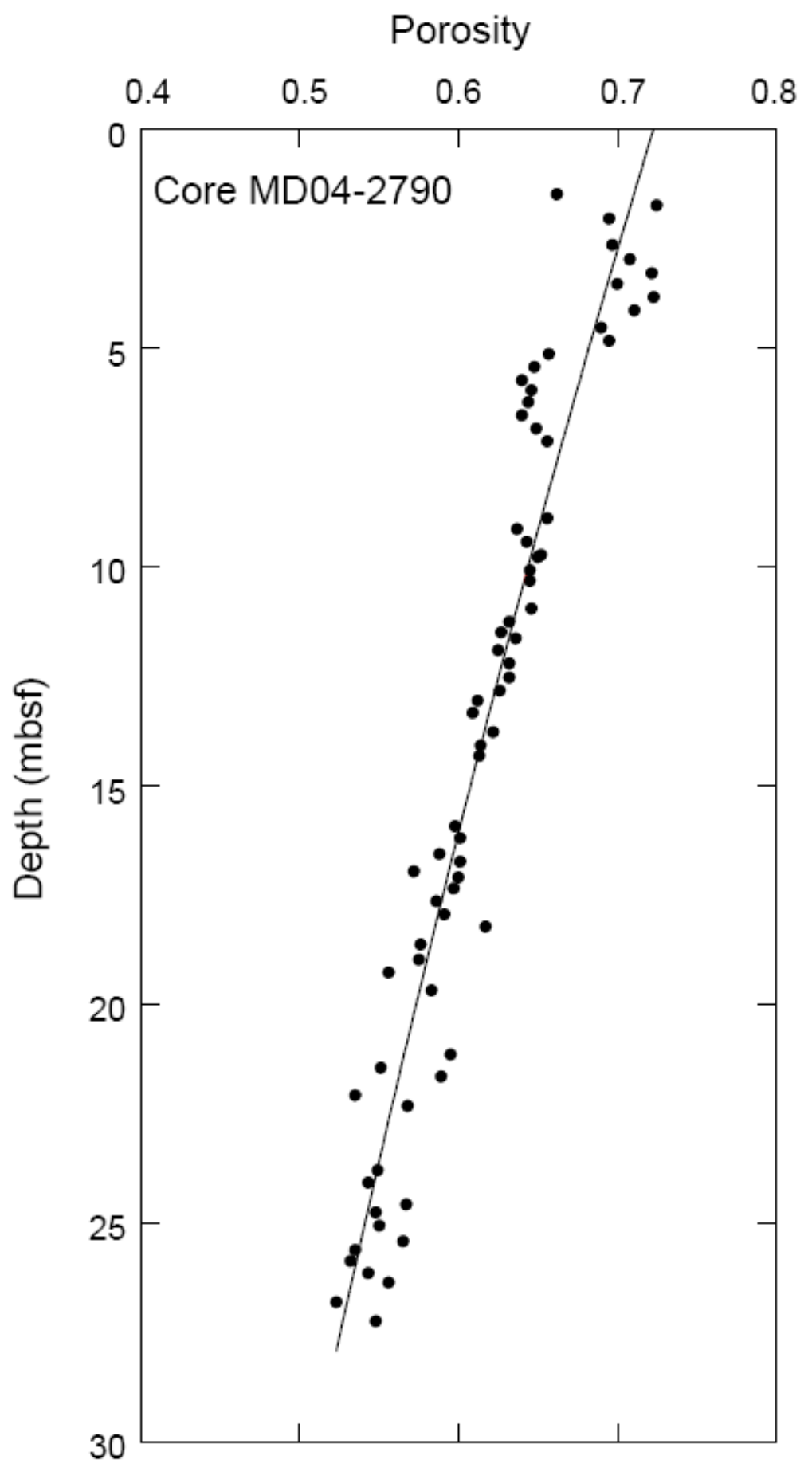

\section{Appendix B}

\section{APPENDIX B}

Porosity profile

Since the sediment of core MD04-2770 was perturbed during pore water sampling, we measured porosity in the laboratory on the sister core MD04-2790. Samples were generally taken every $0.30 \mathrm{~m}$ with $5 \mathrm{~mL}$-syringes. Each sample was weighted, dried for 48 hours at $70^{\circ} \mathrm{C}$, and re-weighted in order to infer the water mass. We assumed that the pores were saturated with water, which allowed us to calculate porosity as a volume proportion. Due to 
the core length, porosity data only covered the first $30 \mathrm{mbsf}$ and varied between 0.71 and 0.51 . At greater depths (below approximately $300 \mathrm{mbsf}$ ) the porosity of sediments recovered in the Black Sea at DSDP sites 379, and 380 of Leg 42B, remained constant at 0.45 (Ross et al., 1978). We assumed the same lower limit for porosity in our site. Since the advectiondiffusion model requires a continuous function of porosity vs. depth, the data were fitted with an exponential function (Fig. B):

$\phi(z)=\phi_{\infty}+\left(\phi_{0}-\phi_{\infty}\right) \cdot \exp \left(-\frac{Z}{z_{a}}\right)$

The best fit $\left(R^{2}=0.90, n=70\right)$ is obtained for a surface porosity (at zero depth) of $\Phi_{0}=0.75$, an asymptotic porosity at a great depth $\Phi_{\infty}=0.45$, with an attenuation coefficient $z_{a}=22 \mathrm{~m}$.

\section{Reference}

Ross, D.A., Neprochnov, Y.P., Degens, E.T., Erickson, A.J., Hsü, K., Hunt, J.M., Manheim, F.T., Percival, S., Senalp, M., Stoffers, P., Supko, P., Traverse, A., Trimonis, E.A., 1978. Tabulated physical property data - LEG 42B, In: Ross, D.A., Neprochnov, Y.P., al., e. (Eds.), Initial Reports of the Deep Sea Drilling Project. U.S. Government Printing Office, Washington, pp. 1131-1137.

Figure caption

Black dots are the porosity data from core MD04-2790. The black line is the exponential fit of the data. 